ESTIMATION OF NATURAL DISSOLVED-SOLIDS DISCHARGE

IN THE UPPER COLORADO RIVER BASIN,

WESTERN UNITED STATES

By David K. Mueller and Lisa L. Osen

U.S. GEOLOGICAL SURVEY

Water-Resources Investigations Report 87-4069

Prepared in cooperation with the

U.S. BUREAU OF RECLAMATION

Denver, Colorado

1988 
DEPARTMENT OF THE INTERIOR

DONALD PAUL HODEL, Secretary

U.S. GEOLOGICAL SURVEY

Dallas L. Peck, Director

For additional information write to:

District Chief

U.S. Geological Survey

Water Resources Division

Box 25046, Mail Stop 415

Federal Center

Denver, CO 80225-0046
Copies of this report can be purchased from:

U.S. Geological Survey

Books and Open-File Reports

Federal Center, Bldg. 810

Box 25425

Denver, CO 80225-0425 


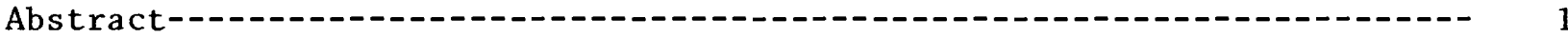

Introduction-1

Purpose and scope-- 3

History and effects of water-resources development---n 5

Previous investigations--- 6

Acknowledgments-_-_- 6

Data availability---n-- 7

Mass-balance estimation of natural dissolved-solids discharge---_------- 8

Development of a statistical method for estimation of natural dissolved-

solids discharge--- 13

Selection of independent variables-a

Selection of model form-- 16

Evaluation of seasonal variation--

Comparison of model estimates to mass-balance estimates------- 18

Selected model--.-- 23

Sensitivity to mass-balance estimates---on 23

Revisions to the selected model-- 24

Equalization of residual variance---n- 24

Detransformation and bias correction-- 26

Outline of the statistical method-_- 28

Estimation of natural dissolved-solids discharge using the statistical method--.-

Verification of the statistical model-_. 40

Summary------on 42

References--- 45

Supplemental information- 47

\section{FIGURES}

Figure 1. Map showing location of the Upper Colorado River Basin and sites selected for analysis in this study-..- 2

2-3. Plots of:

2. Residuals versus predicted dissolved-solids discharge for sites 1,3 , and 9 used in model testing-----

3. Weighted residuals versus weighted predicted dissolvedsolids discharge for sites 1,3 , and 9 used in model

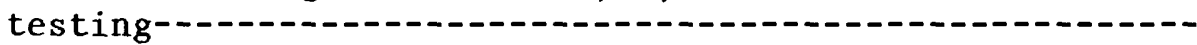

4-8. Plots of monthly mean natural dissolved-solids concentrations for sites along:

4. The Colorado River and the Gunnison River----

5. The Green River and the Colorado River at Lees Ferry, Ariz.--1.- 36

6. The San Juan River and the Colorado River at Lees Ferry, Ariz.---.--

7. Tributaries of the Green River-a

8. The Dolores and the San Rafael Rivers---

9. Graph showing comparison of estimated and measured dissolvedsolids discharge for samples collected during water years 1905-6-0.-. 


\section{TABLES}

Table 1. Selected data for 16 sites used in this study-10.--

2. Mass balance for site 2, streamflow-gaging station 09095500 Colorado River near Cameo, Colo., for water years 1914-57--

3. Transbasin diversions used in the mass-balance analyses,

1957 level of development
4. Summary of mean annual (water years 1914-57) natural dissolved-solids discharge and streamflow at the 16 sites--

5. Statistics for models with constant and periodic (seasonally variable) exponent, $b$, at sites 1,3 , and 9-...-

6. Comparison of natural dissolved-solids discharge estimated by the statistical models and by the annual mass balance for sites 1, 3, and 9--

7. Significance of changes in regression-coefficient values following model recalibration, sites 1,3 , and 9--..--

. Monthly coefficients $\left(\hat{a}_{m}\right)$ and exponents $(\hat{b})$ for the 16 sites in the model:

$\hat{D}_{N}=\hat{a}_{m} \ell_{N}^{\hat{b}}$

9. Estimates of monthly mean natural dissolved-solids discharge for the 16 sites (water years 1906-83)

10. Independent variable selection and model results for the 16

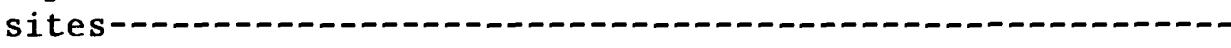

11. Summary of natural dissolved-solids discharge and streamflow for reaches between sites during water years 1906-83-.----

12-26. Mass balance for:

12. Site 1, water-quality station 09071100 Colorado River near Glenwood Springs, Colo., for water years 1914-57-_.-.-

13. Site 3, streamflow-gaging station 09152500 Gunnison River near Grand Junction, Colo., for water years 1914-57-.--

14. Site 4, streamflow-gaging station 09180000 Dolores River near Cisco, Utah, for water years 1914-57-.....-

15. Site 5, streamflow-gaging station 09180500 Colorado River near Cisco, Utah, for water years 1914-57-_-..--

16. Site 6, streamflow-gaging station 09211200 Green River below Fontenelle Reservoir, Wyo., for water years 1914-57-_...-

17. Site 7, streamflow-gaging station 09217000 Green River near Green River, Wyo., for water years 1914-57--.-----

18. Site 8 , streamflow-gaging station 09234500 Green River near Greendale, Utah, for water years 1914-57-_-

19. Site 9, streamflow-gaging station 09251000 Yampa River near Maybe11, Colo., for water years 1914-57----.---.-

20. Site 10, streamflow-gaging station 09302000 Duchesne River near Randlett, Utah, for water years 1914-57--..-

21. Site 11, streamflow-gaging station 09306500 White River near Watson, Utah, for water years 1914-57-_.-. 
Tables 12-26. Mass balance for--Continued:

Page

22. Site 12, streamflow-gaging station 09315000 Green River

at Green River, Utah, for water years 1914-57---1---- 58

23. Site 13, streamflow-gaging station 09328500 San Rafael

River near Green River, Utah, for water years 1914-57---

24. Site 14, streamflow-gaging station 09355500 San Juan River near Archuleta, N. Mex., for water years 1914-57-------

25. Site 15, streamflow-gaging station 09379500 San Juan River near Bluff, Utah, for water years 1914-57--.-.--

26. Site 16, streamflow-gaging station 09380000 Colorado River at Lees Ferry, Ariz., for water years 1914-57--.-----

\section{CONVERSION FACTORS}

Inch-pound units in this report may be converted to metric (International System) units by using the following conversion factors:

Multiply inch-pound units

acre
acre-foot
acre-foot per acre
acre-foot per month
acre-foot per year
mile
square mile
ton per acre
ton, short
ton per month
ton per year

By

$$
4,047
$$$$
1,233
$$

1,233

1,233

1.609

2.590

0.2242

0.9072

0.9072

0.9072
To obtain SI units

square meter cubic meter

cubic meter per square meter

cubic meter per month cubic meter per year kilometer square kilometer kilogram per square meter megagram megagram per month megagram per year

Another term used in this report is:

milligram per liter 


\title{
ESTIMATION OF NATURAL DISSOLVED-SOLIDS DISCHARGE \\ IN THE UPPER COLORADO RIVER BASIN, WESTERN UNITED STATES
}

By David K. Mueller and Lisa L. Osen

\begin{abstract}
A statistical method was developed to estimate monthly natural dissolvedsolids discharge at selected sites in the Upper Colorado River Basin. Natural dissolved-solids discharge was defined as the rate of inorganic-solute flow past a specific site that would have occurred if there had been no waterresources development in the basin upstream from the site. The method used weighted least-squares regression to fit a model of dissolved-solids discharge as a function of streamflow and several variables representing development. After the model had been calibrated for an individual site, the development variables were assigned a value of zero to yield a relation between dissolvedsolids discharge and streamflow for conditions of no upstream development. Natural dissolved-solids discharge was calculated using this relation and estimates of natural streamflow provided by the U.S. Bureau of Reclamation.

Limitations of the method included lack of data to adequately represent all the effects of development and verify the estimates of monthly natural dissolved-solids discharge; however, model statistics indicated a good correlation between the estimates and historical data. Also, the estimates of natural dissolved-solids discharge had the expected monthly distribution and were consistent between upstream and downstream sites.
\end{abstract}

\section{INTRODUCTION}

The Colorado River system is one of the most regulated and most legislated in the world. It provides water for more than 12 million people and for approximately 2.5 million acres of agricultural land (U.S. Bureau of Reclamation, 1983). However, most of the Colorado River basin is arid or semiarid, and the average runoff is much smaller than that for other similarly sized river basins in the United States.

The Colorado River basin has a total area of 244,000 square miles, including parts of Mexico and seven States (Arizona, California, Colorado, Nevada, New Mexico, Utah, and Wyoming). It is legally divided into an upper and lower basin at a point on the Colorado River 1 mile downstream from the mouth of the Paria River and 2 miles downstream from the streamflow-gaging station at Lees Ferry, Arizona. The Upper Colorado River Basin (fig. 1) has an area of approximately 113,000 square miles, of which approximately 4,000 square miles is noncontributing, including the Great Divide Basin and nearby areas in Wyoming. Mean annual streamflow at Lees Ferry was approximately 10 million acre-feet from 1942 through 1983 (U.S. Department of the Interior, 1985). 


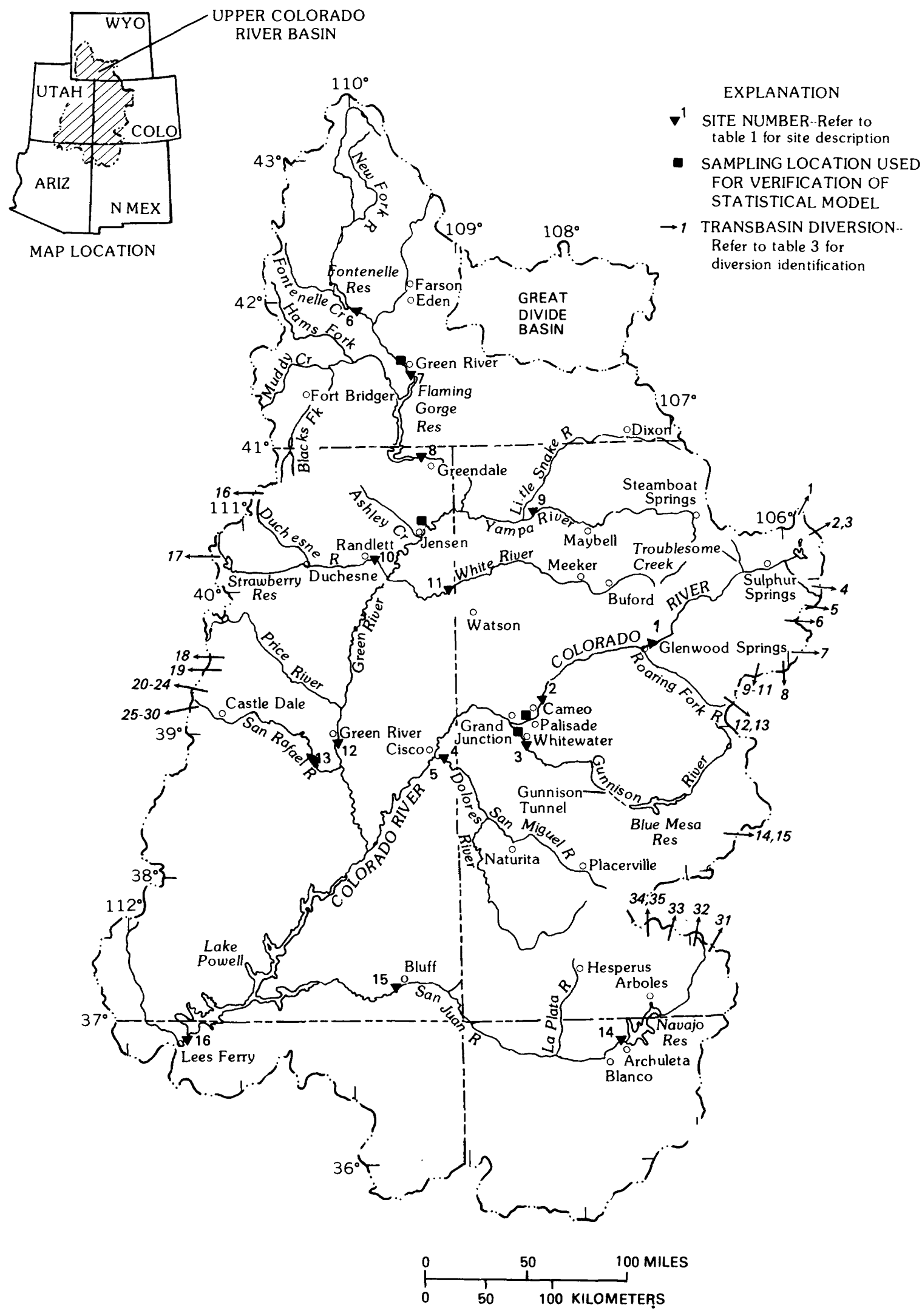

Figure 1.--Location of the Upper Colorado River Basin and sites selected for analysis in this study. 
Salinity has long been a water-quality issue in the Colorado River basin. (As used here, salinity is synonymous with dissolved-solids concentration as a measure of the inorganic-solute copcentration in water.) The Colorado River Basin Water-Quality Control Project was established in 1960 by the U.S. Public Health Service to evaluate the most critical pollution problems in the basin. By 1963, "...salinity was identified as a pressing problem..." (U.S. Environmental Protection Agency, 1971, p. 2) and detailed studies were initiated. During 1972, concerned with increasing dissolved-solids concentrations, the seven basin States adopted a nondegradation policy for the Lower Colorado River. The Colorado River Basin Salinity Control Program was proposed to offset salinity increases that were expected to occur because of planned water-resources development in the Upper Colorado River Basin. The Colorado River Basin Salinity Control Act of 1974 gave primary responsibility for the Salinity Control Program to the U.S. Bureau of Reclamation.

At that time, the U.S. Bureau of Reclamation was developing a comprehensive river-basin model for studying the operation of reservoirs on the Colorado River system. To evaluate Salinity Control Program options, dissolved-solids routing was incorporated into the model. The model consists of a package of computer programs and data bases known as the Colorado River Simulation System (CRSS). It operates on a monthly time-step using the hydrologic record from 1906 through 1983 adjusted to natural conditions (U.S. Bureau of Reclamation, 1985). Mass-balance estimates of dissolved-solids discharge are computed by subtracting the dissolved-solids discharge diverted and adding the discharge contributed by water-resources-development projects to the discharge that would have been present under natural conditions. This computation requires estimates of natural dissolved-solids discharge for all the river reaches used in the model. Dissolved-solids discharge, as used in this report, is defined as the load, or mass, of inorganic solutes flowing past a specific site during a unit of time. Natural dissolved-solids discharge is the discharge that would have existed at the site if there had been no water-resources development upstream.

\section{Purpose and Scope}

The present study was conducted to provide the U.S. Bureau of Reclamation with consistent, realistic estimates of natural dissolved-solids discharge for use in the CRSS model. The purpose of this report is to:

1. Describe a method for estimating the natural dissolved-solids discharge at a site, using the historical streamflow and dissolved-solids data for the site and the data for water-resources development upstream from the site.

2. Present estimates of monthly natural dissolved-solids discharge for 16 sites in the Upper Colorado River Basin.

The sites selected for analysis and the corresponding periods of record are listed in table 1 , and the location of each site is shown in figure 1. Headwater sites are defined as the most upstream on the respective rivers; all other sites are classified as downstream sites. 


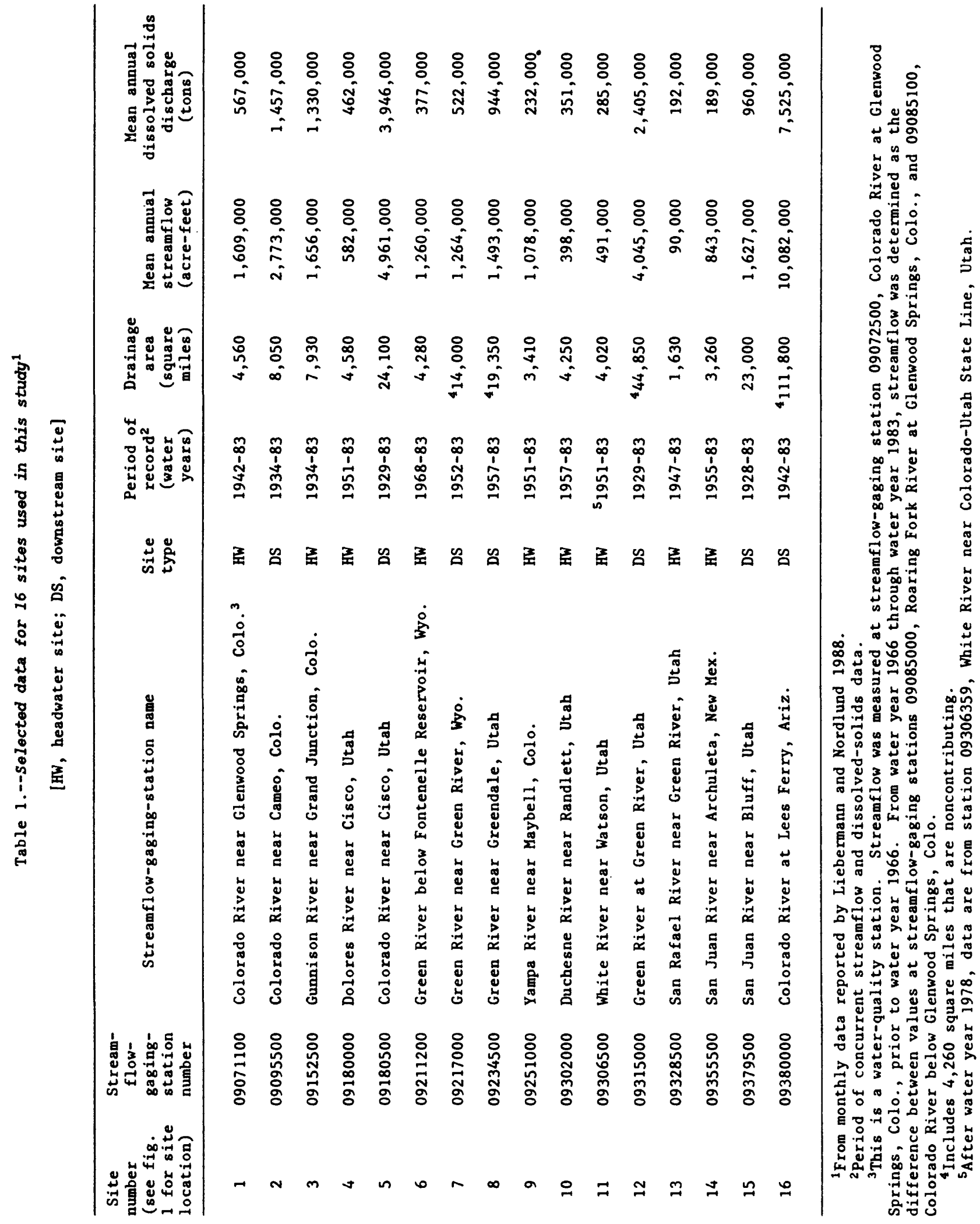




\section{History and Effects of Water-Resources Development}

Development of water resources for irrigation in the Upper Colorado River Basin began with the earliest non-Indian settlement. The first diversion for irrigation was begun in 1854 along the Blacks Fork near Fort Bridger, Wyo. (Wooley, 1930). The first cooperative effort to supply water to a large area was begun in 1883 in the Grand Valley, near Grand Junction, Colo. (Follansbee, 1929). Irrigation development accelerated following passage of the Reclamation Act of 1902, which provided Federal funds for storage and conveyance facilities. Approximately 800,000 acres were being irrigated in the Upper Colorado River Basin by 1905 and nearly 1.4 million acres by 1920 (U.S. Department of the Interior, 1985). Since then, irrigated area has remained relatively constant between 1.4 and 1.6 million acres. Consumptive use by agriculture during 1940-80 averaged 2.18 million acre-feet annually, which was approximately 21 percent of the mean annual streamflow at Lees Ferry, Ariz., during the same period (U.S. Bureau of Reclamation, written commun., 1985).

Irrigated agriculture is the largest anthropogenic source of dissolvedsolids loading in the Upper Colorado River Basin. Drainage water from irrigated land dissolves mineral salts from soil and aquifer material and returns to the stream system with a greater dissolved-solids load than was originally diverted. This process is called "salt pickup." Iorns and others (1965) estimated the long-term average contribution of dissolved-solids from irrigated land would be approximately 40 percent of the annual dissolvedsolids discharge from the Upper Colorado River Basin at the level of development that existed in 1957.

Transbasin diversion of water from the Upper Colorado River Basin also began early in the settlement period. In 1892, the Grand River Ditch began diverting water from the Colorado River headwaters to the Platte River basin. By water year $1920,120,000$ acre-feet were being diverted annually to the Platte River, Arkansas River, and Rio Grande basins in Colorado and New Mexico, and to the Great Basin in Utah. Diversions increased substantially between water years 1950 and 1980 to about 800,000 acre-feet per year. During water years 1973-82, diversions averaged approximately 5 percent of the natural streamflow at Lees Ferry, Ariz. (Liebermann and others, 1988). Transbasin diversions remove dissolved solids as well as water; however, because most diversions occur in headwater areas where dissolved-solids concentrations are small, the decrease in dissolved-solids discharge is small compared to the decrease in streamflow in the basin.

Construction of large reservoirs lagged substantially behind development of irrigation and transbasin diversion facilities in the Upper Colorado River Basin. The first reservoir that had a capacity greater than 100,000 acre-feet was Strawberry Reservoir, completed in 1912 on the Duchesne River in Utah. Total storage capacity in the Upper Colorado River Basin increased to 2.5 million acre-feet by 1962. Then, during 1962-65, four major reservoirs of the U.S. Bureau of Reclamation's Colorado River Storage Project were completed (Navajo Reservoir in New Mexico and Colorado, Flaming Gorge Reservoir in Utah and Wyoming, Lake Powell in Arizona and Utah, and Blue Mesa Reservoir in Colorado), and storage capacity was increased to almost 37 million acre-feet. This was more than three times the mean annual streamflow at Lees Ferry, Ariz. 
Reservoirs have a complex effect on downstream water quality. The primary effect of a large reservoir is a decrease in the seasonal and annual variation in dissolved-solids concentration downstream from the reservoir, because of mixing within the reservoir (Moody and Mueller, 1984). Downstream from Lake Powell, the largest reservoir in the Upper Colorado River Basin, the standard deviation of monthly dissolved-solids concentrations decreased from 299 milligrams per liter before the reservoir began filling (1941-62) to 72 milligrams per liter after initial filling was completed (1965-83). Similarly, the standard deviation of annual dissolved-solids concentrations decreased from 106 to 42 milligrams per liter (Liebermann and Nordlund, 1988).

In comparison to irrigation, transbasin diversions and reservoir storage, other types of water-resources development in the Upper Colorado River Basin have had only a minor effect on dissolved-solids concentration and discharge.

\section{Previous Investigations}

Early reports on the Upper Colorado River Basin (LaRue, 1916; Follansbee, 1929; Wooley, 1930) focused on water-supply concerns and made little or no mention of water quality. Stabler (1911) presented chemical analyses of samples collected from several locations in the basin during 1905 and 1906, but he did not include any interpretive material.

The first comprehensive study of water quality in the Upper Colorado River Basin was conducted by Iorns and others (1965). They estimated the mean annual dissolved-solids discharge at 30 locations in the basin assuming hydrologic conditions from water years $1914-57$ and the 1957 level of waterresources development. The mean annual values of dissolved-solids discharge then were apportioned into the quantities derived from natural sources and from anthropogenic sources.

In a similar study, the U.S. Environmental Protection Agency (1971) evaluated the relative contribution of dissolved solids from natural and anthropogenic sources throughout the Upper and Lower Colorado River Basins. This evaluation resulted in the first predictions of increasing dissolvedsolids concentrations in the Lower Colorado River Basin, which would be caused by planned water-resources development.

In 1982 , studies were initiated to provide more accurate, consistent estimates of historical monthly dissolved-solids loads in the basin (Kircher and others, 1984; Moody and Mueller, 1984; Mueller and Moody, 1984; Liebermann and others, 1987). The resultant estimates were reported by the U.S. Department of the Interior (1985) and were evaluated by Liebermann and others (1988).

\section{Acknowledgments}

The authors wish to thank John Billings, Jerold Lazenby, and David Trueman of the U.S. Bureau of Reclamation, Salt Lake City, for providing some 
of the data used in the analysis and much valuable advice and discussion on development of the statistical method.

\section{DATA AVAILABILITY}

At the beginning of this study, available data were reviewed to determine the type of analysis possible for estimating natural dissolved-solids discharge for water years 1906-83, which is the period used in operation of the CRSS model. Daily streamflow and periodic water-quality data for part of this period were available from the U.S. Geological Survey's National Water Data Storage and Retrieval System (WATSTORE) (Hutchinson, 1975); monthly streamflow and dissolved-solids discharge previously had been computed from these data (U.S. Department of the Interior, 1985; Liebermann and others, 1987). The periods of record for the monthly values are listed in table 1 for the sites included in this report.

The U.S. Bureau of Reclamation provided estimates of annual irrigated area, monthly consumptive use by agriculture, and monthly natural streamflow from the CRSS data set for each site during 1906-83. The irrigated-area data had been compiled from several sources, including: State Engineer reports, census data, Colorado River Storage Project estimates, State agricultural statistics, Colorado Water Conservation Board reports, and others (U.S. Bureau of Reclamation, written commun., 1978). Because of inconsistencies in computational methods, the irrigated-area data for 1976-83 was disregarded in the analysis for most of the sites.

Agricultural consumptive use, as defined in the CRSS data set, is the difference between the volume of water diverted for irrigation and the volume of water that eventually returns to the stream. Therefore, consumptive use includes all evaporative losses during conveyance and application, crop transpiration, and phreatophyte transpiration along the canals and return-flow paths. It does not include evapotranspiration of natural precipitation. The monthly consumptive-use data were estimated by the U.S. Bureau of Reclamation using a modified version of the Blaney-Criddle formula (U.S. Soil Conservation Service, 1970). The areal extent of specific crops was estimated using county census data.

The U.S. Bureau of Reclamation computed natural streamflow as the sum of the historic streamflow and adjustments representing upstream development. Total adjustments included agricultural consumptive use, transbasin diversions, reservoir effects, municipal and industrial use, and incidental depletions. Monthly import and export data were obtained from the U.S. Geological Survey and irrigation districts. Reservoir effects consisted of evaporation and changes in surface and bank storage. Evaporation for each reservoir was computed by multiplying the monthly average water-surface area by the monthly rate of evaporation. Changes in bank storage were estimated as 10 percent of the change in surface storage. Monthly municipal and industrial use was estimated by uniformly distributing annual powerplant consumptive use. Incidental depletions accounted for such losses as stock-pond evaporation and fish and wildlife use. For periods when historical streamflow data were unavailable, the natural-flow values were estimated using regression techniques (U.S. Bureau of Reclamation, written commun., 1983). 
Iorns and others (1965) reported estimates of annual anthropogenic dissolved-solids discharge for selected locations in the Upper Colorado River Basin. These estimates were computed to represent the mean annual dissolvedsolids discharge that would be expected if the water-resources developments existing in 1957 had been in operation during the hydrologic conditions that occurred from water years 1914 through 1957. Iorns and others (1965) also estimated the dissolved-solids discharge that could be attributed to irrigation and municipal and industrial uses, and the dissolved-solids discharge imported or exported in transbasin diversions.

Geologic and geographic information about the basin is extensive. Geologic and topographic maps of the five upper basin States--Arizona, Colorado, New Mexico, Utah, and Wyoming--were used in the study to delineate irrigated areas that have the potential for saline return flows. Iorns and others (1965) provided a detailed description of the geologic conditions in the basin.

Chemical analyses of samples collected from a few locations in water years 1905 and 1906 were reported by Stabler (1911) and summarized on a monthly basis by Iorns and others (1965). These data were not included in the statistical-model calibrations, but were used for a limited verification of the models.

\section{MASS-BALANCE ESTIMATION OF NATURAL DISSOLVED-SOLIDS DISCHARGE}

Iorns and others (1965) estimated the mean annual dissolved-solids discharge from natural and anthropogenic sources at several locations in the Upper Colorado River Basin. The purpose of their study was to quantify the effects of water-resources development on dissolved-solids loading in specific river reaches. The entire discharge entering the upstream end of a reach was considered natural, even though it also may have been affected by development. To determine the natural dissolved-solids discharge required in the present study, certain adjustments had to be made to the estimates of Iorns and others (1965). Generally these adjustments involved adding the discharge that had been removed by upstream transbasin diversions and subtracting the discharge that had been contributed by upstream irrigation. Estimates for several reaches had to be combined to produce the natural discharge at some of the sites used in the present study. If Iorns and others (1965) did not provide an estimate for part of the drainage area upstream from a site, the dissolvedsolids discharge from that area was determined based on the evaluation by Iorns and others (1965) of areas with similar geology, physiography, and land use.

The mass balance for site 2, the Colorado River near Cameo, Colo., is shown in table 2. The total drainage area is 8,050 square miles and the irrigated area in 1957 was 163,400 acres. Iorns and others (1965) reported the historical mean streamflow to be 2,998,000 acre-feet per year and the dissolved-solids discharge to be 1,578,000 tons per year for hydrologic conditions during water years $1914-57$ adjusted to the 1957 level of development. 
Table 2.--Mass balance for site 2, streamflow-gaging station 09095500 Colorado River near Cameo, Colo., for water years 1914-571

$$
[--, \text { no data }]
$$

\begin{tabular}{|c|c|c|c|c|}
\hline Mass-balance component & $\begin{array}{l}\text { Drainage } \\
\text { area } \\
\text { (square } \\
\text { miles) }\end{array}$ & $\begin{array}{c}\text { Irrigated } \\
\text { area } \\
\text { (acres) }\end{array}$ & $\begin{array}{l}\text { Mean annual } \\
\text { streamflow } \\
\text { (acre-feet) }\end{array}$ & $\begin{array}{c}\text { Mean annual } \\
\text { dissolved- } \\
\text { solids } \\
\text { discharge } \\
\text { (tons) }\end{array}$ \\
\hline \multicolumn{5}{|l|}{ Historical conditions } \\
\hline Colorado River near Cameo, Colo....... & 8,050 & 163,400 & $2,998,000$ & $1,578,000$ \\
\hline \multicolumn{5}{|l|}{ Adjus tments for development } \\
\hline $\begin{array}{l}\text { Irrigation: } \\
\quad \text { Roaring Fork River basin } \\
\text { Remaining drainage area }\end{array}$ & $\begin{array}{l}1,451 \\
2,039\end{array}$ & $\begin{array}{l}31,400 \\
48,300\end{array}$ & $\begin{array}{l}(+) 34,540 \\
(+) 77,830\end{array}$ & $\begin{array}{l}(-) 107,800 \\
(-) 144,910\end{array}$ \\
\hline $\begin{array}{l}\text { Transbasin diversions: } \\
\text { Twin Lakes tunnel and } \\
\text { Busk-Ivanhoe tunnel- }\end{array}$ & --- & --- & $2(+) 37,500$ & $(+) 3,060$ \\
\hline $\begin{array}{l}\text { Effects in upstream areas: } \\
\text { Colorado River near Glenwood } \\
\text { Springs, Colo. }\end{array}$ & 4,560 & 83,700 & $\underline{(+) 395,350}$ & $(-) 108,260$ \\
\hline \multicolumn{5}{|l|}{ Natural conditions } \\
\hline Colorado River near Cameo, Colo...... & $-\cdots$ & -- & $3,543,220$ & $1,220,090$ \\
\hline $\begin{array}{l}\text { Estimated mean annual natural dissolved-s } \\
255 \text { milligrams per liter }\end{array}$ & olids cc & cation & water yea & $-57:$ \\
\hline
\end{tabular}

${ }^{1}$ Based on Iorns and others (1965).

${ }^{2}$ Mean annual value for water years 1954-57. 
The drainage area for site 2 includes that of site 1 , the Colorado River at Glenwood Springs, Colo., and the intervening area between the two sites. Iorns and others (1965) computed the mass balance in the Roaring Fork River basin, which is part of the intervening drainage area. They estimated that 34,540 acre-feet of water would have been consumptively used annually on 31,400 acres of irrigated 1 and and between 94,200 and 121,400 tons per year of dissolved solids would have been added to the Roaring Fork River because of development. The midpoint of this range, 107,800 tons per year, was used in table 2 as the dissolved-solids discharge contributed by irrigation in the Roaring Fork River basin. For the remaining intervening drainage area, Iorns and others (1965) estimated that 77,830 acre-feet of water per year would have been consumptively used on 48,300 acres of irrigated land and 144,910 tons per year of dissolved solids would have been added because of development.

The historical conditions for site 2 did not include the water or dissolved solids removed in transbasin diversions through the Twin Lakes and the Busk-Ivanhoe tunnels in the Roaring Fork River basin (a11 transbasin diversions referred to in the mass-balance analyses are listed in table 3 and their locations are shown in figure 1). The exported streamflow and dissolvedsolids discharge was added in the mass balance to estimate natural conditions. Iorns and others (1965) reported the mean annual diversion for water years 1954-57 to be 37,500 acre-feet and estimated the dissolved-solids concentration as 60 milligrams per liter. Based on these estimates, 3,060 tons per year of dissolved solids were exported from the basin.

To complete the mass balance, anthropogenic effects in the upstream area had to be considered. From a previous mass balance for site 1 , the Colorado River near Glenwood Springs, Colo., an estimated 395,350 acre-feet per year of water would have been consumptively used because of development in the basin and an estimated 108,260 tons per year of dissolved solids would have been added to the reach.

The natural dissolved-solids discharge for site 2, the Colorado River near Cameo, Colo., then was computed by subtracting the dissolved-solids discharge contributed by irrigation from the historical dissolved-solids discharge at the site. The dissolved-solids discharge contributed by upstream development also was subtracted, and the dissolved-solids discharge removed in transbasin exports was added. Natural streamflow was computed by adding alI the water consumptively used by development to the historical streamflow. The resulting mean annual natural streamflow for water years 1914-57 was 3,543,220 acre-feet and the mean annual natural dissolved-solids discharge was 1,220,090 tons. Based on these values, the mean annual dissolved-solids concentration at the site would have been approximately 255 milligrams per liter during 1914-57 had there been no development in the basin.

Mass-balance computations for the other 15 sites considered in this study are tabulated in the "Supplemental Information" section at the back of this report. A summary of results is reported in table 4. This table also includes the mean annual natural streamflow estimated by the U.S. Bureau of Reclamation for water years 1914-57 (U.S. Bureau of Reclamation, written commun., 1983), which were slightly different from the mass-balance estimates. Because the estimates of natural dissolved-solids discharge from this report were intended to be used in conjunction with the U.S. Bureau of Reclamation's 
Table 3.--Transbasin diversions used in the mass-balance analyses, 1957 level of development

Number

(see fig. 1

Name

for location)

Grand River ditch

Alva B. Adams tunnel

Eureka ditch

Moffat Water tunnel

Berthoud Pass ditch

Jones Pass tunnel

Boreas Pass ditch

Hoosier Pass ditch

Columbine ditch

Ewing ditch

Wurtz ditch

Busk-Ivanhoe tunnel

Twin Lakes tunnel

Larkspur ditch

Tabor ditch

Duchesne tunnel

Strawberry River diversions (includes Strawberry tunnel, Strawberry River ditch, Willow Creek ditch, and Hobble Creek ditch)

Fairview ditch

Candland ditch

Coal Fork ditch

Twin Creek ditch

Black Canyon ditch

Cedar Creek ditch

Spring City tunnel

Ephraim tunnel

Larsen tunnel

Horseshoe tunnel

Reeder ditch

Madsen ditch

John August ditch

Treasure Pass ditch

Piedra Pass ditch

Squaw Pass ditch

Fuchs ditch

Raber-Lohr ditch 


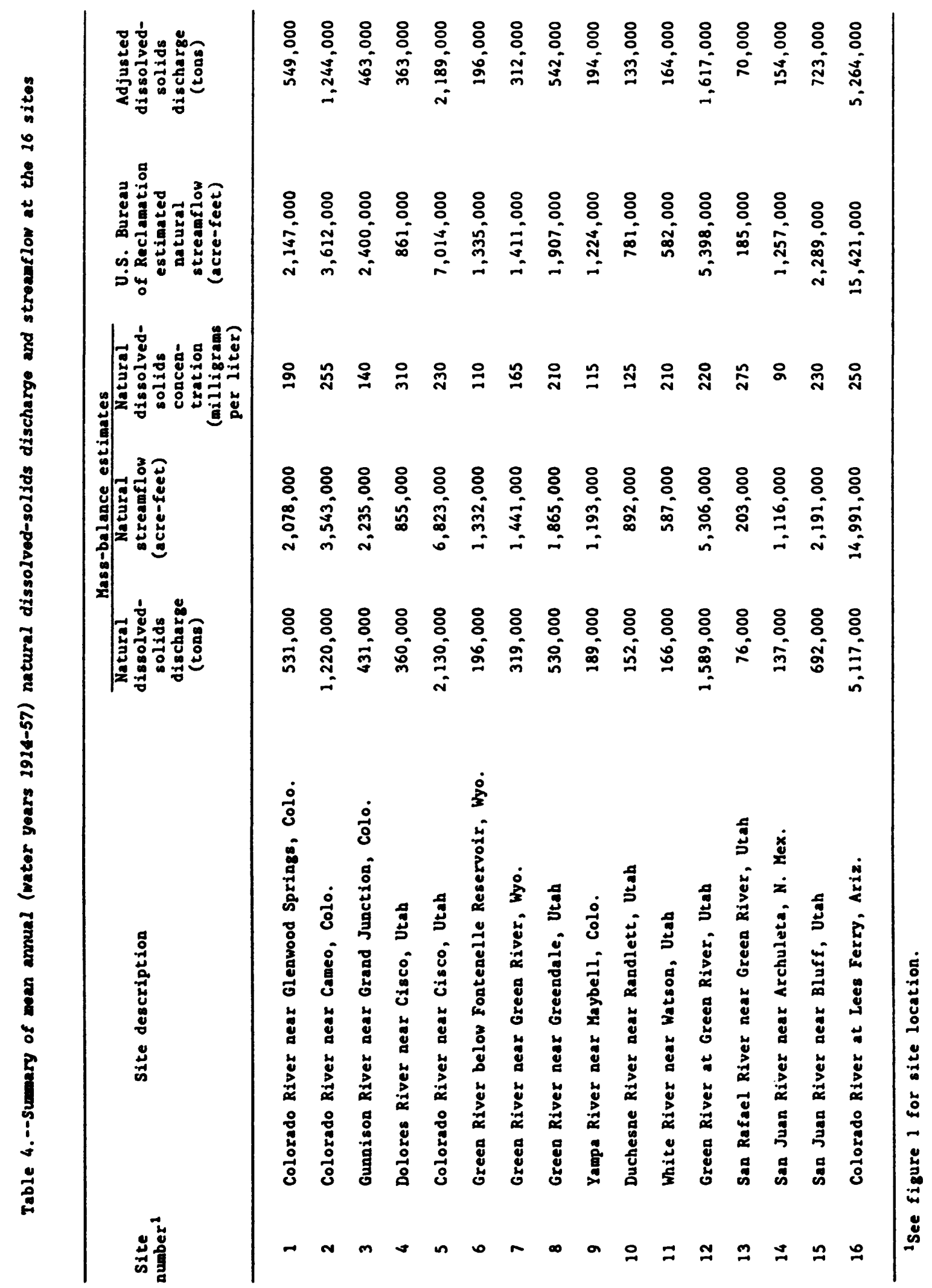


natural streamflow values, the mass-balance estimates of dissolved-solids discharge were adjusted by the ratio of the two streamflow values. The adjusted estimates of mean annual dissolved-solids discharge are listed in table 4 and are used as the values of mean annual natural dissolved-solids discharge throughout the remainder of this report.

The accuracy of the natural dissolved-solids discharge estimated by this mass-balance procedure cannot be determined because Iorns and others (1965) provided little information on the uncertainty of their computed and estimated values. Occasionally they gave a range of values for an unmeasured component of the mass balance, but the maximum total range was always within 8 percent of the mean discharge. If the uncertainty in all components had been considered, the range would be greater than 8 percent. An upper limit for the error in natural dissolved-solids discharge can be estimated, because all the study sites are affected by anthropogenic sources of dissolved solids, and the historical discharge must be greater than the natural discharge. The ratios of historical to natural discharge for the study sites ranged from 16 to 242 percent, with a median of 60 percent.

\section{DEVELOPMENT OF A STATISTICAL METHOD FOR ESTIMATION OF NATURAL DISSOLVED-SOLIDS DISCHARGE}

Data available for this report were inadequate for estimating monthly natural dissolved-solids discharge by mass balance. An alternative approach was to formulate a statistical model of dissolved solids as a function of historical streamflow and other variables representing upstream waterresources development. The calibrated model then could be used to compute monthly natural dissolved-solids discharge by assuming a value for natural streamflow and assigning all the development variables a value of zero.

\section{Selection of Independent Variables}

Monthly data on water-resources development upstream from each site analyzed in this report were provided by the U.S. Bureau of Reclamation (written commun., 1983). The variables related to development were:

1. Total adjustments to streamflow, which included consumptive use, transbasin diversions, and change in reservoir storage.

2. Consumptive use.

3. Upstream irrigated area.

These available development variables were indicators of two processes: a decrease in dissolved-solids discharge because of diversions, or an increase in discharge because of salt pickup. Within this conceptual framework, releases from storage could be considered negative diversions, resulting in an increase in dissolved-solids discharge.

The variables indicative of diversion were total adjustments to streamflow and consumptive use. Because consumptive use was included in the total adjustments value, these two variables usually were strongly correlated. To decrease the possibility of collinearity among the selected independent variables, two new variables were defined based on the difference between 
total adjustments and consumptive use. When total adjustments exceeded consumptive use, the difference was considered to be a net diversion for other purposes, such as municipal and industrial use, transbasin diversion, or an increase in reservoir storage. When consumptive use exceeded total adjustments, the difference was considered to be a net release from storage. In the fitted models, the coefficient for consumptive use was expected to be negative, because it is an indicator of agricultural diversions that would remove dissolved-solids from the stream. Likewise, the coefficient for net other diversions was expected to be negative. Net release was expected to have a positive coefficient because additional dissolved solids would be included in the supplemental streamflow. The coefficient for total adjustments could be either positive or negative, but normally was expected to be negative because annual diversions were larger than releases for most sites.

The only variable available as an indicator of salt pickup was upstream irrigated area. Because upstream irrigated area was reported as an annual value, it provided no information on monthly fluctuations. To achieve better monthly resolution, consumptive-use values from each of the previous 4 months were included as independent variables. Salt pickup by irrigation return flow during a specific month then could be indicated as a linear combination of consumptive use during the previous 4 months. Optimally, the resulting combination would indicate the monthly and yearly distributions of return flows that occurred in the basin. Such a relation between consumptive use and return flow assumes: (1) Return flow lags irrigation application by 1 to 4 months, and (2) consumptive use is an indicator of the total irrigation application during a specific month. The first assumption depends on the hydraulic conductivity in the soil-aquifer system underlying the irrigated area and the distance from the application site to a surface drain. A 1- to 4-month lag indicates that for an irrigation season from April through October and maximum consumptive use during June and July, return flow could occur from May through February and be maximum between July and November. Such a return-flow pattern seems reasonable for irrigated areas in the Upper Colorado River Basin. Data from sites downstream from large irrigated areas usually indicate that a substantial volume of return flow occurs during September and October (Moody and Mueller, 1984). The second assumption, that consumptive use is an indicator of irrigation application, also is reasonable. Irrigation efficiency, the ratio of consumptive use to applied water, remains fairly constant from year to year when evaluated for large areas. During a 3-year study of the Grand Valley, near Grand Junction, Colo., Loftis (1983) reported no significant differences in mean annual efficiency. Long-term changes in irrigation efficiency generally occur only in areas where farmers have substantially changed their irrigation practices. In the fitted models, irrigated area and consumptive use in preceding months were expected to have positive coefficients, because they were indicators of return flow that would add dissolved solids to the stream.

The final set of development variables was:

Indicators of diversion or release:

1. Total adjustments to streamflow.

2. Consumptive use.

3. Net other diversions.

4. Net release. 
Indicators of salt pickup:

1. Irrigated area (annual value).

2. Consumptive use in the preceding month.

3. Consumptive use in the second preceding month.

4. Consumptive use in the third preceding month.

5. Consumptive use in the fourth preceding month.

For downstream sites (table 1), these variables were summed for all tributary upstream reaches. The models then were calibrated using variables that indicated the total water-resources development upstream from the site.

Selection of independent variables for individual sites was made using stepwise-regression procedures. Four separate methods were used: (1) Backward elimination, (2) forward selection, (3) stepwise selection, and (4) maximum $\mathrm{R}^{2}$ improvement (SAS Institute Inc., 1985). Also, the diversion indicators were divided into three groups to evaluate the effects of collinearity among the diversion indicators. One group included only total adjustments; the second included only the components of total adjustments-consumptive use, net other diversions, and net release; and the third included all four of the diversion indicators. This combination of 4 methods and 3 groups of variables produced 12 separate selection options for a particular model calibration.

Several secondary criteria were applied to distinguish among options and determine the overall best variable set. The first of these secondary criteria was to minimize the mean-square error. The second criterion was that the Mallows' Cp statistic approximately equal the number of parameters in the model. This minimizes the bias in the standard error caused by an overparameterized model (Montgomery and Peck, 1982). The third criterion was that - the coefficients for the development variables have the expected sign. The fourth criterion was that the model contain no strongly correlated variables or combinations of variables. This criterion was intended to decrease the collinearity among the independent variables. As a check for possible collinearity, the variance inflation factors (VIF's) were evaluated for the selected variable sets. The VIF for a coefficient is a measure of the increase in the variance of that coefficient caused by correlation among the independent variables in the model. If VIF's are large, the associated coefficients may be poorly estimated (Montgomery and Peck, 1982).

In practice, the variable sets selected by the four stepwise regression procedures usually were identical; therefore, the choice was only among the three variable groups. Normally, one of these groups was clearly superior in regard to all the secondary selection criteria. 


\section{Selection of Model Form}

An equation commonly used to relate the concentration of dissolved solids to streamflow (Ha11, 1970 and 1971; Lane, 1975; Steele, 1976; DeLong, 1977) is of the form:

$$
c=a Q^{b}
$$

where

$$
\begin{aligned}
& C=\text { dissolved-solids concentration, in milligrams per liter; } \\
& Q=\text { streamflow, in cubic feet per second; } \\
& a=\text { an empirical coefficient; and } \\
& b=\text { an empirical exponent. }
\end{aligned}
$$

The data available for this report were monthly dissolved-solids discharge, streamflow, and data representing the level of development in the Upper Colorado River Basin. Dissolved-solids discharge $(D)$ is the product of dissolved-solids concentration and streamflow:

$$
D=C Q \text {. }
$$

Combining equations 1 and 2 yields:

$$
D=a Q^{b+1} .
$$

Equation 3 relates dissolved-solids discharge to streamflow. However, the model selected for this report needed to incorporate independent variables representing water-resources development. In addition, the relation between dissolved-solids and streamflow in the fitted model had to be reasonable for natural conditions when all the development variables were set equal to zero. Three model forms were tested to determine which would most adequately meet the requirements. These were:

$$
\begin{aligned}
\text { Additive model: } & D_{H}=a Q_{N}^{b}+\Sigma c_{i} X_{i}, \\
\text { Power model: } & D_{H}=a Q_{H}^{b} \Pi\left(X_{i}+1\right)^{c} i, \text { and }
\end{aligned}
$$

$$
\text { Exponential model: } D_{H}=a Q_{H}^{b} \exp \left(\Sigma c_{i} X_{i}\right) \text {, }
$$

where

$D_{H}=$ historical dissolved-solids discharge, in tons per month;

$Q_{N}=$ natural streamflow, in acre-feet per month;

$\ell_{H}=$ historical streamflow, in acre-feet per month;

$x_{i}=$ development variables (appropriate units); and

$c_{i}=$ the coefficient or exponent for the $i$ th development variable. 
The additive model is appealing because a physical interpretation could be given to each term. If the relation between the dissolved-solids discharge and streamflow under natural conditions is assumed to be a power function, then the additive model indicates that development in the basin increases the dissolved-solids discharge or, where there are exports from the basin, decreases the discharge. The historical discharge, therefore, is the sum of the natural dissolved-solids discharge from the basin and the discharge due to development within the basin.

In the power and exponential models, the development variables are empirical factors that change the historical relation between dissolved-solids discharge and streamflow as development increases. Historical streamflow was used to calibrate these models. An important attribute of both these models is that they can be rewritten in linear form and the coefficients evaluated using linear regression:

$$
\text { Power model: } \ln \left(D_{H}\right)=\ln (a)+b \ln \left(Q_{H}\right)+\Sigma c_{i} \ln \left(X_{i}+1\right) \text {, and }
$$

Exponential model: $\ln \left(D_{H}\right)=\ln (a)+b \ln \left(Q_{H}\right)+\Sigma c_{i} X_{i}$.

\section{Evaluation of Seasonal Variation}

To account for seasonal variation in the relation between dissolvedsolids and streamflow (eq. 1), Lane (1975) and DeLong (1977) incorporated periodic functions of time into the empirical coefficient (a) and empirical exponent (b). DeLong (1977) used the formulation:

$$
\begin{aligned}
& a=\exp \left(a_{0}+a_{1} \sin (t)+a_{2} \cos (t)\right), \text { and } \\
& b=b_{0}+b_{1} \sin (t)+b_{2} \cos (t),
\end{aligned}
$$

where

$$
t=a \text { function of time, and }
$$

$$
a_{0}, a_{1}, a_{2}, b_{0}, b_{2}=\text { empirical parameters. }
$$

Lane (1975) found a strong linear correlation between the periodic values of $a$ and $b$ that were determined using this formulation. Such a correlation can result in poorly estimated regression coefficients and limit the usefulness of the model for extrapolation (Montgomery and Peck, 1982).

For all the models used in the present study, parameters $a$ and $b$ were evaluated as periodic functions. Then the VIF's of the periodic terms were checked for indications of collinearity. In the linearized power and exponential models (eq. 7 and 8 ), the parameters $a$ and $b$ were of the same form used by DeLong (1977), given previously in equations 9 and 10 . In the additive model (eq. 4), the empirical coefficient (a) was computed as a summation rather than an exponential function:

$$
a=a_{0}+a_{1} \sin (t)+a_{2} \cos (t) \text {. }
$$


In all cases, $t$ was computed such that the period of the harmonic function was 1 year:

$$
t=\frac{2 \pi(m)}{12},
$$

where $\quad m=$ month of the calendar year.

In general, when seasonality was included only in the coefficient $a$, all periodic terms were significant at the 95-percent level. Also, the VIF's for all terms normally were less than 10. This indicated there was no significant multicollinearity in the models (Montgomery and Peck, 1982). However, when both the coefficient $a$ and the exponent $b$ included seasonality, the periodic terms usually were not significant and the VIF's generally were greater than. 100 , which indicated poor estimation of the regression coefficients.

To avoid the problems associated with multicollinearity, seasonal variation was restricted to the coefficient $a$, and the exponent $b$ was held constant. The effect of this restriction on model fit was negligible, as is indicated by the data in table 5. The standard error and the coefficient of determination $\left(R^{2}\right)$ are given for models with periodic exponents and constant exponents. For three test sites, the largest decrease in $R^{2}$ caused by removal of seasonal variation from the exponent is 0.006 . The largest increase in standard error is 400 tons per month ( 7 percent).

\section{Comparison of Model Estimates to Mass-Balance Estimates}

The best model form was selected from among the additive, power, and exponential models by comparing model estimates of natural dissolved-solids discharge to the mass-balance estimates. Values of monthly natural dissolvedsolids discharge were computed using the calibrated models with the development terms set to zero and the natural-streamflow estimates provided by the U.S. Bureau of Reclamation (written commun., 1983). The mean annual natural dissolved-solids discharge estimated by each model for the water years 1914-57 was then compared to the mass-balance estimate for the same period.

The initial model estimates of mean annual natural dissolved-solids discharge did not compare well to the mass-balance estimates for three test sites (table 6). Also, estimates varied considerably among the models. For example, the model estimates for site 3 varied from 200 to $1,218,000$ tons per year, and none were close to the mass-balance estimate of 463,000 tons per year. This variation probably occurred because the true values of natural dissolved-solids discharge were outside the range of the historical data used to fit the models. Since water-resources development in the Upper Colorado River Basin began long before collection of water-quality data and development of irrigated areas was similar to current (1986) conditions by the 1920's, the period of record used to fit the models was not representative of conditions prior to development. To estimate natural conditions, extrapolation beyond the range of the historical data was necessary; such extrapolation can produce large errors. 
Table 5.--statistics for models with constant and periodic (seasonally variable) exponent, $b$, at sites 1,3 , and 9

\begin{tabular}{ccc} 
Mode1 & Standard & \\
Exponent & $\begin{array}{c}\text { error } \\
\text { (tons per } \\
\text { month) }\end{array}$ & $\begin{array}{c}\text { Coefficient } \\
\text { determination, } \\
R^{2}\end{array}$ \\
\hline
\end{tabular}

Site 1, Colorado River near Glenwood Springs, Colorado ${ }^{1}$

$\begin{array}{llrr}\text { Additive } & \text { Periodic } & 4,500 & 0.95 \\ \text { Additive } & \text { Constant } & 4,800 & 0.95 \\ \text { Power } & \text { Periodic } & 5,000 & 0.94 \\ \text { Power } & \text { Constant } & 5,100 & 0.94 \\ \text { Exponential } & \text { Periodic } & 5,000 & 0.94 \\ \text { Exponential } & \text { Constant } & 5,000 & 0.94\end{array}$

Site 3, Gunnison River near Grand Junction, Colorado ${ }^{1}$

$\begin{array}{llcr}\text { Additive } & \text { Periodic } & 17,300 & 0.86 \\ \text { Additive } & \text { Constant } & 17,700 & 0.85 \\ \text { Power } & \text { Periodic } & 17,800 & 0.85 \\ \text { Power } & \text { Constant } & 17,600 & 0.86 \\ & & & \\ \text { Exponential } & \text { Periodic } & 16,200 & 0.88 \\ \text { Exponential } & \text { Constant } & 16,300 & 0.88\end{array}$

Site 9, Yampa River near Maybel1, Colorado ${ }^{1}$

\begin{tabular}{llcc} 
Additive & Periodic & 4,600 & 0.94 \\
Additive & Constant & 4,800 & 0.94 \\
Power & Periodic & 5,000 & 0.94 \\
Power & Constant & 5,100 & 0.93 \\
& & & \\
Exponential & Periodic & 5,200 & 0.93 \\
Exponential & Constant & 5,100 & 0.93 \\
\hline
\end{tabular}

${ }^{1}$ Refer to figure 1 for site locations. 
Table 6.--Comparison of natural dissolved-solids discharge estimated by the statistical models and by the annual mass balance for sites 1, 3, and 9

\begin{tabular}{ccccc}
\hline Site & Model & $\begin{array}{c}\text { Standard } \\
\text { error } \\
\text { (tons per } \\
\text { month) }\end{array}$ & $\begin{array}{c}\text { Coefficient } \\
\text { of deter- } \\
\text { mination, } \\
R^{2}\end{array}$ & $\begin{array}{c}\text { Mean annul (water years 1914-57) } \\
\text { natural dissolved-solids discharge } \\
\text { (tons) }\end{array}$ \\
\hline
\end{tabular}

$\underline{\text { Initial model calibration--historical data }}$

\begin{tabular}{|c|c|c|c|c|}
\hline Additive & 4,800 & 0.95 & 451,000 & 549,000 \\
\hline Power & 5,100 & 0.94 & $1,981,000$ & 549,000 \\
\hline Exponential & 5,000 & 0.94 & 709,000 & 549,000 \\
\hline Additive & 17,400 & 0.85 & $1,082,000$ & 463,000 \\
\hline Power & 17,600 & 0.86 & 200 & 463,000 \\
\hline Exponential & 16,500 & 0.87 & $1,218,000$ & 463,000 \\
\hline Additive & 4,800 & 0.94 & 236,000 & 194,000 \\
\hline Power & 5,100 & 0.93 & 0 & 194,000 \\
\hline Exponential & 5,100 & 0.93 & 3,400 & 194,000 \\
\hline
\end{tabular}

Model recalibration--predevelopment estimates included

\begin{tabular}{|c|c|c|c|c|c|}
\hline \multirow[t]{3}{*}{1} & Additive & 4,700 & 0.95 & 485,000 & 549,000 \\
\hline & Power & 5,200 & 0.94 & 214,000 & 549,000 \\
\hline & Exponential & 5,000 & 0.94 & 562,000 & 549,000 \\
\hline \multirow[t]{3}{*}{3} & Additive & 18,800 & 0.84 & 810,000 & 463,000 \\
\hline & Power & 17,900 & 0.86 & 210,000 & 463,000 \\
\hline & Exponential & 16,400 & 0.88 & 487,000 & 463,000 \\
\hline \multirow[t]{3}{*}{9} & Additive & 4,800 & 0.94 & 233,000 & 194,000 \\
\hline & Power & 5,100 & 0.93 & 201,000 & 194,000 \\
\hline & Exponential & 5,000 & 0.94 & 191,000 & 194,000 \\
\hline
\end{tabular}

${ }^{1}$ Refer to figure 1 for site location and table 1 for site description. 
Although the extrapolated estimates of natural dissolved-solids discharge varied among the models, the standard errors for estimating historical discharge generally were similar. The extrapolation differences were the result of differences in incorporation of the development terms in the models. For example, the irrigated area was included as a development variable in all the tested models. It was an annual value that generally varied little from year to year; therefore, it was virtually constant. In the power and exponential models, this variable was a multiplicative factor, which could modify the coefficient for streamflow to such an extent that, when irrigated area was set to zero, the computed natural dissolved-solids discharge was drastically underestimated. The effect of this underestimation is apparent in the powermodel results for site 3 , and the power-model and the exponential-model results for site 9 (table 6 ). The additive model produced more reasonable extrapolation estimates of natural dissolved-solids discharge, particularly for site 9 (table 6$)$.

To decrease the problems associated with extrapolation, estimates of predevelopment dissolved-solids discharge and streamflow were introduced into the calibration data set. These estimates were made by separating the annual mass-balance estimates into monthly values and pairing them with the monthly mean natural streamflows for water years 1914-57. This pairing resulted in 12 estimates of mean monthly dissolved-solids discharge and streamflow that possibly would have occurred if there had been no development in the basin during 1914-57.

Separation of the annual mass-balance estimate of natural dissolvedsolids discharge was based on the monthly distribution of predicted natural discharges given by the initial model calibration. For example, at site 1 , the initial calibration of the exponential model produced an estimate of mean natural dissolved-solids discharge of approximately 709,000 tons per year for water years 1914-57. The estimated mean natural dissolved-solids discharges for individual months ranged from 4.5 to 17.5 percent of the total. The monthly predevelopment discharge estimates used in model recalibration were computed based on these monthly percentages and the mass-balance value of approximately 549,000 tons for mean annual natural dissolved-solids discharge. Separate predevelopment discharge estimates were computed for each model. The predevelopment discharge and streamflow estimates were added to the data set and the model was recalibrated. The predevelopment estimates were then adjusted, based on the new distribution of mean monthly natural discharge, and the model was recalibrated once more.

The results of recalibration of the models with predevelopment discharge and streamflow estimates included in the data sets are reported for the three test sites in table 6 . The standard errors and $R^{2}$ values were virtually unchanged; however, differences between the model and mass-balance values of natural dissolved-solids discharge were greatly decreased, particularly for the exponential model. Substantial differences in standard errors and $R^{2}$ among the models for a specific site occurred only for site 3 , and the exponential model yielded the best results.

Differences in regression coefficient values between models calibrated with and without the predevelopment estimates are listed in table 7 . The intercept term $\left(a_{0}\right)$ of the seasonally variable coefficient (eqs. 9 and 11) 
Table 7.--Significance of changes in regression-coefficient values following model recalibration, sites 1,3 , and 9

Site

number ${ }^{1}$ Mode1 $^{2}$
Student's $t$ for difference in regression coefficient values ${ }^{3,4}$

$\begin{array}{llll}a_{0} & a_{1} & a_{2} & b\end{array}$

1

$$
\text { Additive }
$$

Power

Exponential

Additive

Power

Exponential

9

Additive

Power

Exponential
$2.86 * *$

0.13

$2.72 * *$

0.38

0.33

0.00

0.14

$1.78 \%$

$1.85 *$

0.38

0.43

0.05

0.04

0.35

0.39

0.43

0.28

0.38

0.30

$5.95 \%$

0.43

0.29

0.33

4. $16 * x$

0.22

${ }^{1}$ Refer to figure 1 for site location and table 1 for site description.

${ }^{2}$ Model formulations and coefficients are given in equations $4,7,8,9$, and 11 in sections entitled "Selection of model form" and "Evaluation of seasonal variation".
3 *indicates significant difference at $\mathrm{P}<0.10$
4 *indicates significant difference at $\mathrm{P}<0.05$. 
generally changed significantly following recalibration. Changes in the time terms $\left(a_{1}\right.$ and $\left.a_{2}\right)$ were not significant, except for the additive model at sites 1 and 3. There was a significant change in the exponent (b) for the additive model at sites 1 and 3 and for the power model at site 1 . The exponential model was the most stable. The time terms $\left(a_{1}\right.$ and $\left.a_{2}\right)$ and exponent (b) remained essentially unchanged for all the test sites. The primary effect of adding the predevelopment estimates was a shift in the intercept $\left(a_{0}\right)$. This shift caused the change in the estimates of natural dissolved-solids discharge reported in table 6 . Overall, the exponential model was found to equal or exceed the additive and power models in terms of fit, accuracy, and stability. Therefore, the additive and power models were disregarded in subsequent analyses.

\section{Selected Model}

The linearized exponential model with a periodic coefficient and constant exponent was selected for estimation of natural dissolved-solids discharge at all sites. The true model relating historical discharge to streamflow and development was assumed to be:

$$
\ln \left(D_{H}\right)=a_{0}+a_{1} \sin (t)+a_{2} \cos (t)+b \ln \left(Q_{H}\right)+\sum c_{i} X_{i}+\varepsilon,
$$

where

$$
\varepsilon=\begin{gathered}
\text { random error, which is assumed to be normally distri- } \\
\text { buted with a mean of zero. }
\end{gathered}
$$

The parameters in equation 13 were estimated using the method of least squares. The fitted model was:

$$
\ln \left(\hat{D}_{H}\right)=\hat{a}_{0}+\hat{a}_{1} \sin (t)+\hat{a}_{2} \cos (t)+\hat{b} \ln \left(Q_{H}\right)+\sum \hat{c}_{i} X_{i}
$$

where

$$
\ln \left(\hat{D}_{H}\right)=\text { the predicted value of } \ln \left(D_{H}\right) \text {, and }
$$

$$
\hat{a}_{0}, \hat{a}_{1}, \hat{a}_{2}, \hat{b} \text {, and } \hat{c}_{i}=\text { regression coefficients. }
$$

For any particular observation, the residual was defined as the difference between the actual value of $\ln \left(D_{H}\right)$ and the corresponding prediction from equation 14 .

\section{Sensitivity to Mass-Balance Estimates}

Addition of the estimates of predevelopment streamflow and dissolvedsolids discharge introduced into the data set 12 observations that had a disproportionate influence on the fitted regression model. Recalibration of the exponential model using these data resulted in estimates of natural dissolved-solids discharge that were approximately the same as the massbalance estimates. Because the predevelopment data were derived from the 
mass-balance estimates, the recalibrated model results for natural dissolvedsolids discharge were expected to be sensitive to the mass-balance estimates. A sensitivity analysis was performed to test the effect of variations in the mass-balance estimate on the results of the selected model. Mass-balance estimates of natural dissolved-solids discharge at the test sites were varied within a range of \pm 50 percent of the estimates reported in table 6 . Predevelopment data computed from these mass-balance estimates then were included in the original data set for that site and the model was recalibrated. The resulting model estimates of natural dissolved-solids discharge were changed by almost the same percentage as the change in the mass-balance estimate. This confirmed the importance of accurate mass-balance estimates.

\section{Revisions to the Selected Model}

After its selection as the best model form, the exponential model was tested further to ensure that it satisfied the necessary conditions for adequate regression results. Also, because the actual regression analysis was based on logarithms of dissolved-solids discharge and streamflow, the resultant equation had to be detransformed to estimate natural dissolved-solids discharge.

\section{Equalization of Residual Variance}

One necessary condition for obtaining accurate results from least-squares regression is that the random errors ( $\varepsilon$ in eq. 13) have a constant variance throughout the range of the dependent variable. Violations of the constantvariance assumption can be detected by plotting the predicted values of $\ln \left(D_{H}\right)$ against the residuals.

Initial residual plots for the three test sites are shown in figure 2 . Three different patterns can be observed. For site 1, Colorado River near Glenwood Springs, Colo., the variance of the residuals seems to be reasonably constant throughout the entire range of prediction. However, for site 3 , Gunnison River near Grand Junction, Colo., the variance of the residuals is small at small predicted values of dissolved-solids discharge. Most of these small discharge values are associated with the predevelopment estimates. For site 9, Yampa River near Maybe11, Colo., the variance of the residuals seems to increase slightly with increasing discharge.

The problem of unequal variance can be decreased by differential weighting of the residuals in the least-squares solution. Residuals that tend to be large are given a small weight, and residuals that tend to be small are given a large weight. Weighting factors commonly are computed proportional to the inverse of the residual variance for discrete values of the independent variable. For a continuous variable, such as streamflow, measurements can be divided into classes having a discrete range of values, and the weighting factor can be computed proportional to the inverse of the residual variance within the class (Mongtomery and Peck, 1982, p. 101). In the Colorado River basin, where dissolved-solids discharge has a distinct seasonal pattern, measurements can be classified by month. The maximum discharge occurs during snowmelt runoff, April through July, and the minimum discharge occurs during 


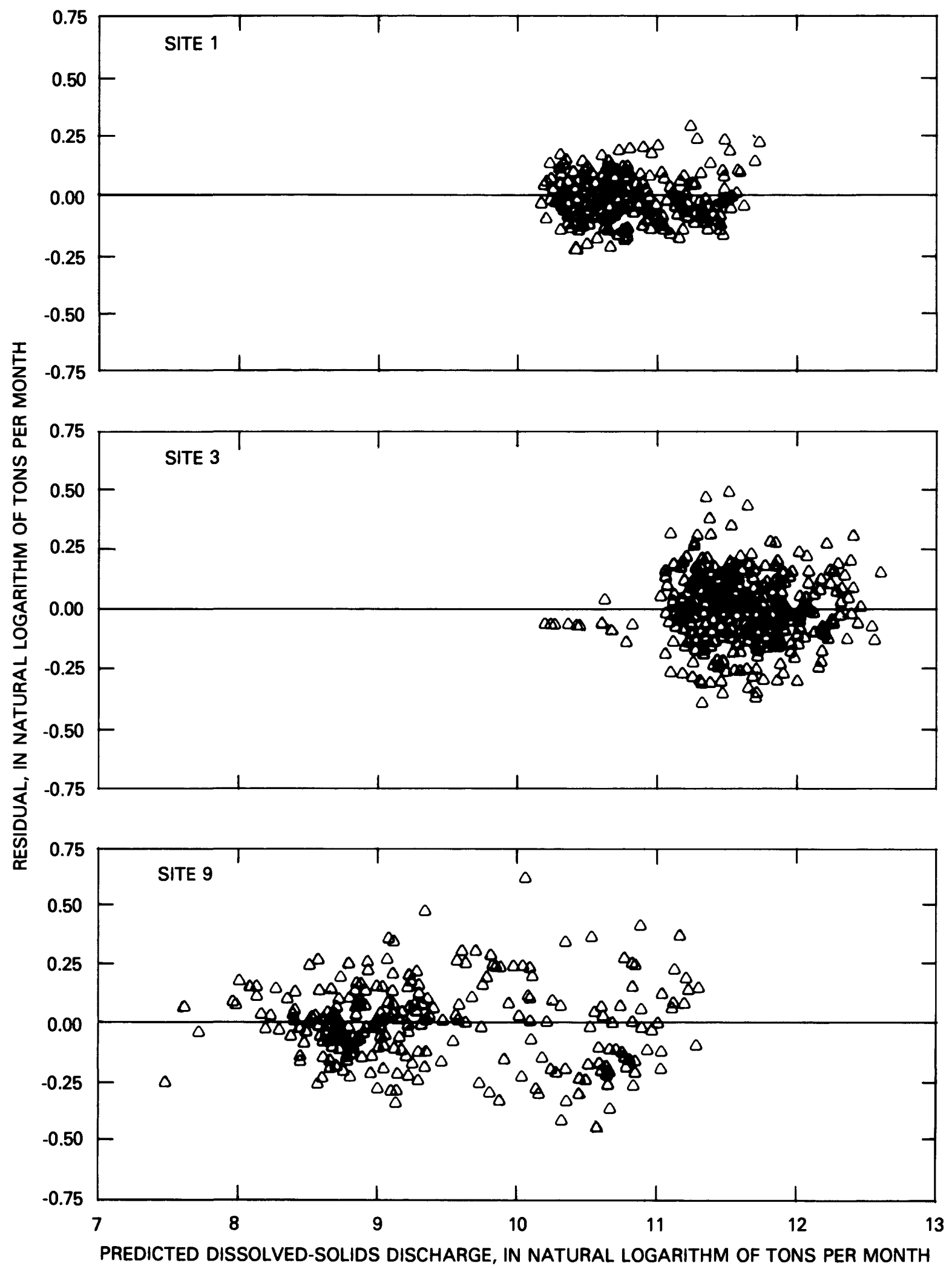

Figure 2.--Residuals versus predicted dissolved-solids discharge for sites 1,3 , and 9 used in model testing. 
winter baseflow, December through February. Therefore, the inverse of the monthly residual variance was considered an appropriate weighting factor.

For site 3, Gunnison River near Grand Junction, Colo., an additional weighting factor was given to the predevelopment estimates in order to equalize their weighted predictions with the remainder of the data set. Predevelopment dissolved-solids discharge at this site was small for every month. Eight of the 12 monthly estimates were smaller than the minimum historical discharge. Therefore, the predevelopment values were considered to be separate from the monthly classification used to determine weighting factors for the historical data. No other site required this type of weighting, because no other predevelopment estimates were so small compared to historical values.

Plots of weighted residuals for the three test sites are shown in figure 3. In all three plots, the variance of weighted residuals is approximately equal throughout the range of predicted values. Therefore, the weighted regression had the desired effect.

\section{Detransformation and Bias Correction}

To predict natural dissolved-solids discharge, the independent variables representing water-resources development in the exponential model (eq. 14) are set to zero. The prediction equation then becomes:

$$
\ln \left(\hat{D}_{N}\right)=\hat{a}_{0}+\hat{a}_{1} \sin (t)+\hat{a}_{2} \cos (t)+\hat{b} \ln \left(Q_{N}\right),
$$

where natural streamflow $\left(Q_{N}\right)$ is used as the independent variable to predict natural dissolved-solids discharge $\left(D_{N}\right)$. When equation 15 is detransformed it becomes:

$$
\hat{D}_{N}=\exp \left(\hat{a}_{0}+\hat{a}_{1} \sin (t)+\hat{a}_{2} \cos (t)\right) Q_{N}^{\hat{b}} \text {. }
$$

Miller (1984) reported that detransformation of a calibrated model can produce a biased estimator of the mean response. Therefore, a bias-correction factor needs to be included in the detransformed equation. For a model fitted to natural logarithms and with normally distributed residuals, Miller (1984) recommended the bias-correction factor (BC) as:

$$
\mathrm{BC}=\exp \left(\frac{1}{2} \hat{\sigma}^{2}\right)
$$

where $\hat{\sigma}^{2}$ is the mean square error, which is an estimator of the residual variance. Miller's (1984) formulation was based on ordinary least-squares regression and needs to be modified for use with weighted least-squares regression. In a weighted least-squares solution, the residual variance is assumed to be nonconstant and is estimated by $\hat{\sigma}^{2} / w_{i}$, where $w_{i}$ is the weighting factor applied to the ith observation. In the present study, observations were classified by month; therefore, the residual variance within a particular month is $\hat{\sigma}^{2} / w_{m}$, where $W_{m}$ is the weighting factor for the month. When this 


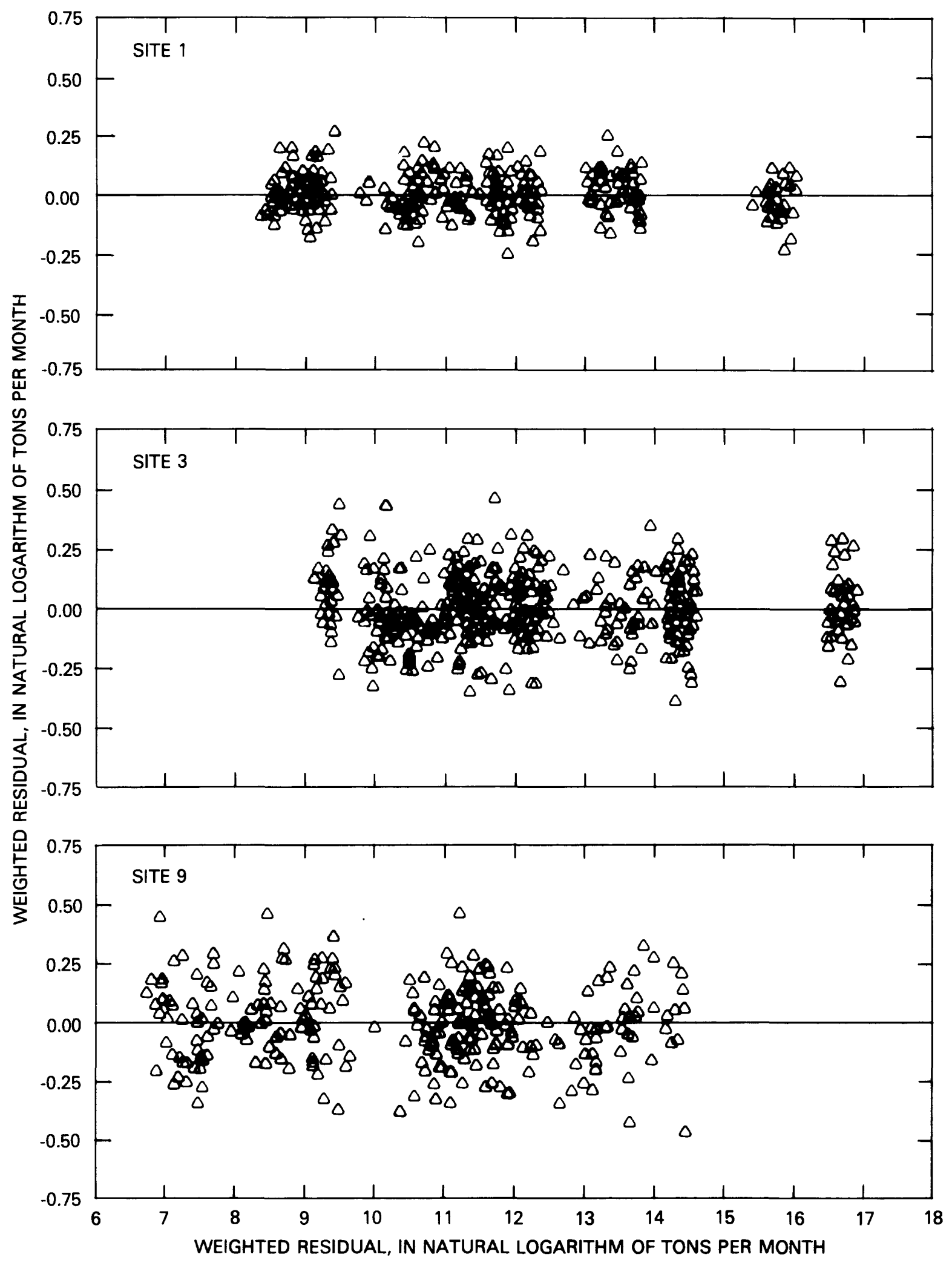

Figure 3.--Weighted residuals versus weighted predicted dissolved-solids discharge for sites 1,3 , and 9 used in model testing. 
residual variance is used in the bias-correction factor, equation 17 can be rewritten:

$$
B C_{m}=\exp \left(\hat{\sigma}^{2} / 2 W_{m}\right)
$$

where

$$
\begin{aligned}
B C_{m} & =\text { the bias-correction factor for month } m, \\
\hat{\sigma}^{2} & =\text { the mean square error of the fitted model, and } \\
W_{m} & =\text { the weighting factor applied to observations within month } m .
\end{aligned}
$$

The detransformed model with bias correction is then:

$$
\hat{D}_{N}=\exp \left(\hat{a}_{0}+\hat{a}_{1} \sin (t)+\hat{a}_{2} \cos (t)\right) Q_{N} \hat{b} \exp \left(\hat{\sigma}^{2} / 2 W_{m}\right)
$$

Because the bias-correction factor and the periodic coefficient are both functions of month, they can be incorporated for convenience and equation 19 can be rewritten:

$$
\hat{D}_{N}=\hat{a}_{m} Q_{N}^{\hat{b}}
$$

where $\hat{a}_{m}$ varies monthly and is defined:

$$
\hat{a}_{m}=\exp \left(\hat{a}_{0}+\hat{a}_{1} \sin (t)+\hat{a}_{2} \cos (t)+\hat{\sigma}^{2} / 2 w_{m}\right)
$$

\section{Outline of the Statistical Method}

Equations 18 and 19 define the model used to compute natural dissolvedsolids discharge for the 16 selected sites in the Upper Colorado River Basin. The regression coefficients $\left(\hat{a}_{0}, \hat{a}_{1}, \hat{a}_{2}\right.$, and $\left.\hat{b}\right)$, monthly weighting factors $\left(w_{m}\right)$, and mean square error $\left(\hat{\sigma}^{2}\right)$ were determined for each site using the following method:

1. Compute the mean annual (water years 1914-57) natural dissolved-solids discharge at the site, using information reported by Iorns and others (1965).

2. Select the independent variables representing water-resources development using step-wise regression.

3. Calibrate the exponential model (eq. 14) using historical data for the site and ordinary least-squares regression. 
4. Separate the annual mass-balance discharge of dissolved solids (computed in step 1) based on the distribution of mean monthly discharge (water years 1914-57) from the model results in step 3.

5. Add the values of monthly dissolved-solids discharge computed in step 4 to the data set. These values represent predevelopment conditions at the site. They are paired with values of mean monthly natural streamflow from the same period (water years 1914-57). All development variables for these predevelopment "observations" are set to zero.

6. Calibrate the model using the predevelopment and historical data.

7. Adjust the values of monthly predevelopment dissolved-solids discharge based on the mean monthly distribution for water years 1914-57 from the model results in step 6 .

8. Recalibrate the model.

9. Compute weighting factors using the monthly residual variances.

10. Recalibrate the model using weighted regression.

11. Repeat steps 9 and 10 , if necessary, until there are no significant differences among the monthly weighted-residual variances.

12. Adjust the values of monthly predevelopment dissolved-solids discharge based on the mean monthly distribution of dissolved-solids discharge for water years 1914-57 obtained from the model results in step 10 .

13. Recalibrate the weighted-regression model.

14. Compute the monthly coefficients $\hat{a}_{m}$ using equation 21 , with time $(t)$ as given by equation 12 .

15. Compute monthly natural dissolved-solids discharge using equation 20, the regression parameters estimated in steps 13 and 14 , and monthly values of natural streamflow.

\section{ESTIMATION OF NATURAL DISSOLVED-SOLIDS DISCHARGE USING THE STATISTICAL METHOD}

The results of applying the outlined statistical method to data from 16 selected sites in the Upper Colorado River Basin are reported in tables 8 and 9 . The coefficient and exponent values used to estimate natural dissolved-solids discharge for each site are listed in table 8 . Estimates of monthly mean natural dissolved-solids discharge for each site are listed in table 9 .

The development variables that were included in the model for each site and the sign (positive or negative) of the associated regression coefficients are listed in table 10 . The $R^{2}$, standard errors of estimation, and comparisons between the mean annual (water years 1914-57) natural dissolved-solids discharge estimated by the statistical method and by mass balance also are listed. The development variables expected to indicate an increase in dissolved-solids discharge were: irrigated area, net reservoir releases, consumptive use in preceding months, and total adjustments to streamflow, if the predominant adjustments were reservoir releases. Net diversions, consumptive use, and total adjustments to streamflow, if predominantly diversions, were expected to indicate a decrease in dissolved-solids discharge. The development variables included in the model for each site generally had the 


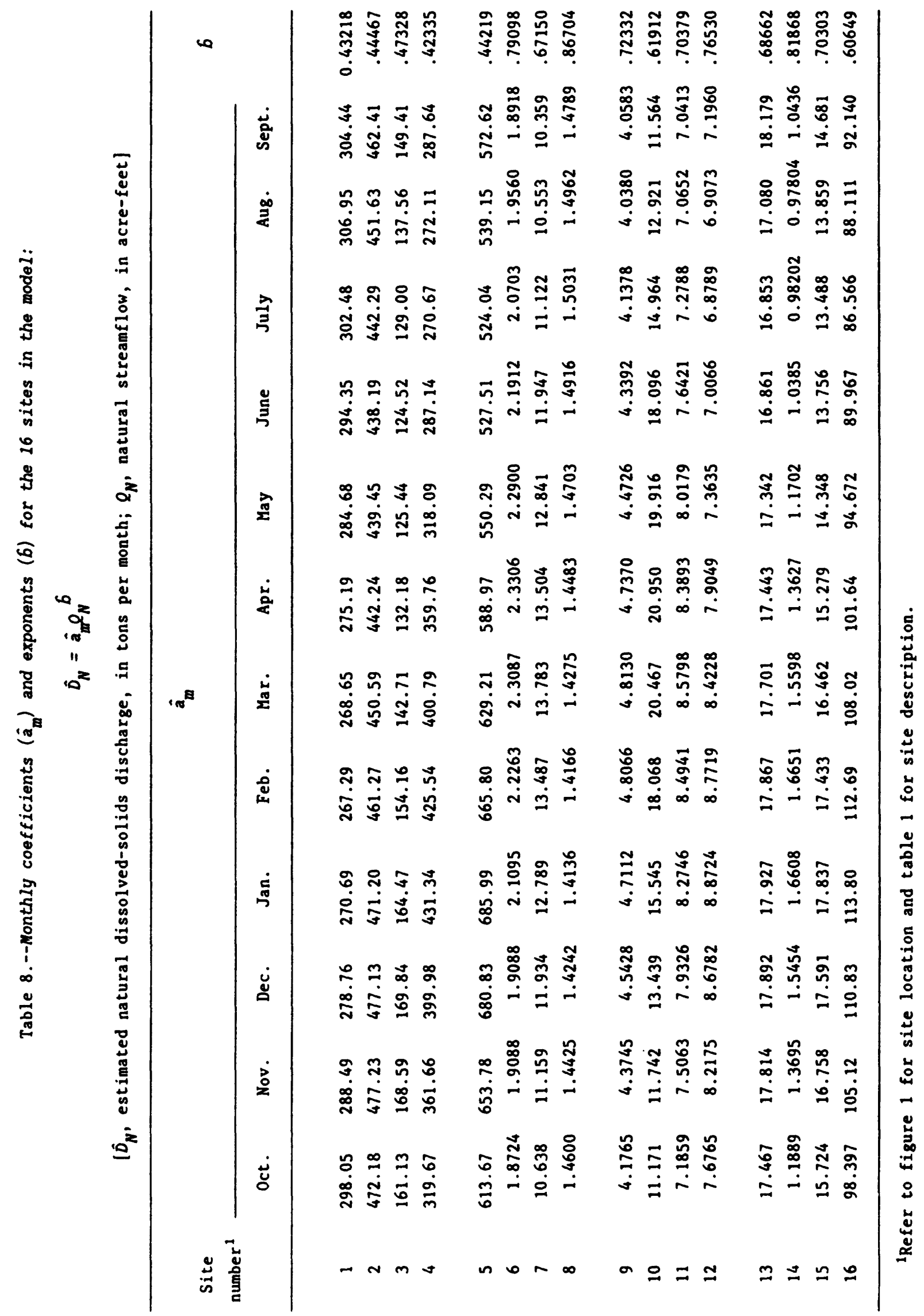




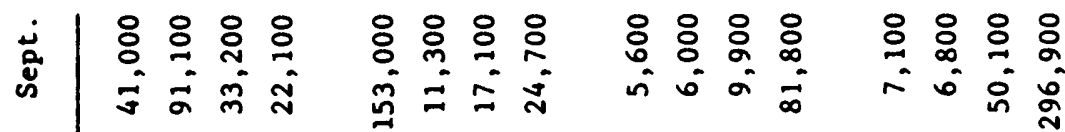

車

ที่

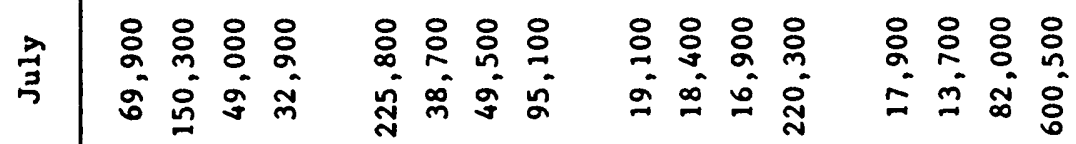

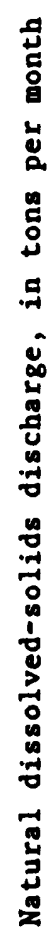

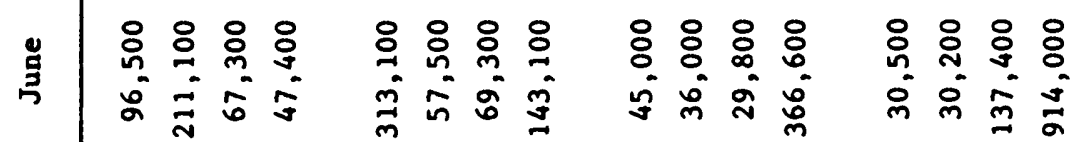

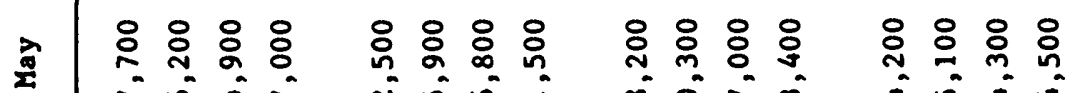

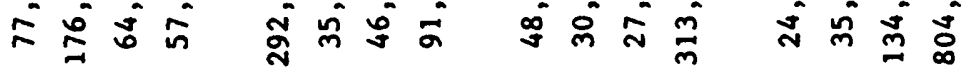

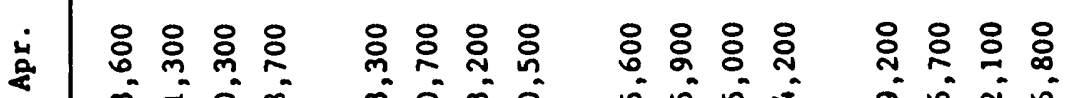

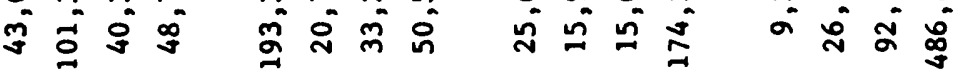

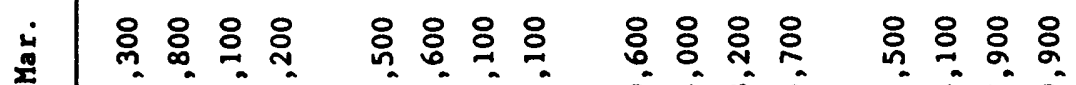

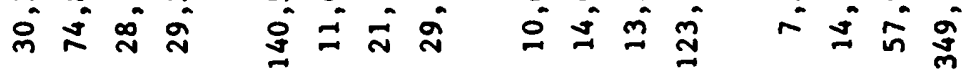

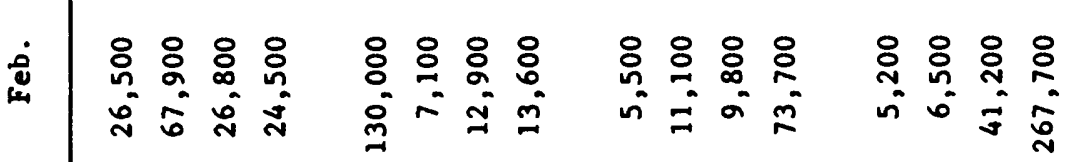

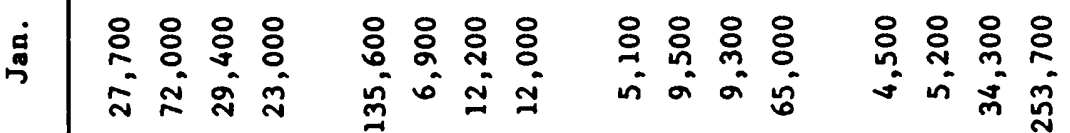

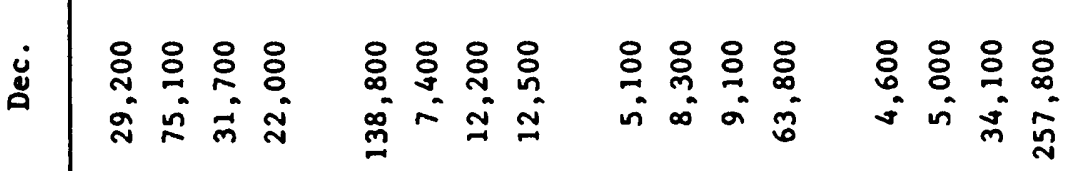

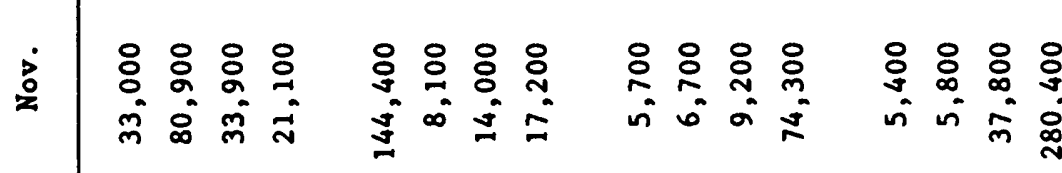

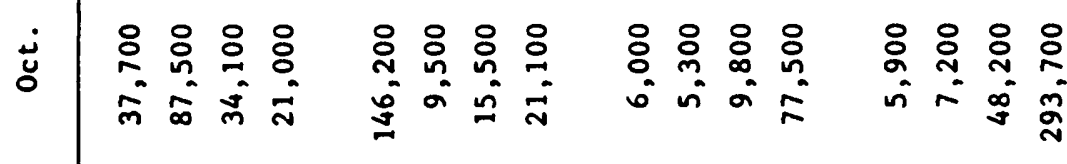

के

$\operatorname{sins}$

$\infty \circ \sim \infty$

$\therefore=2$

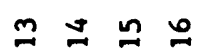




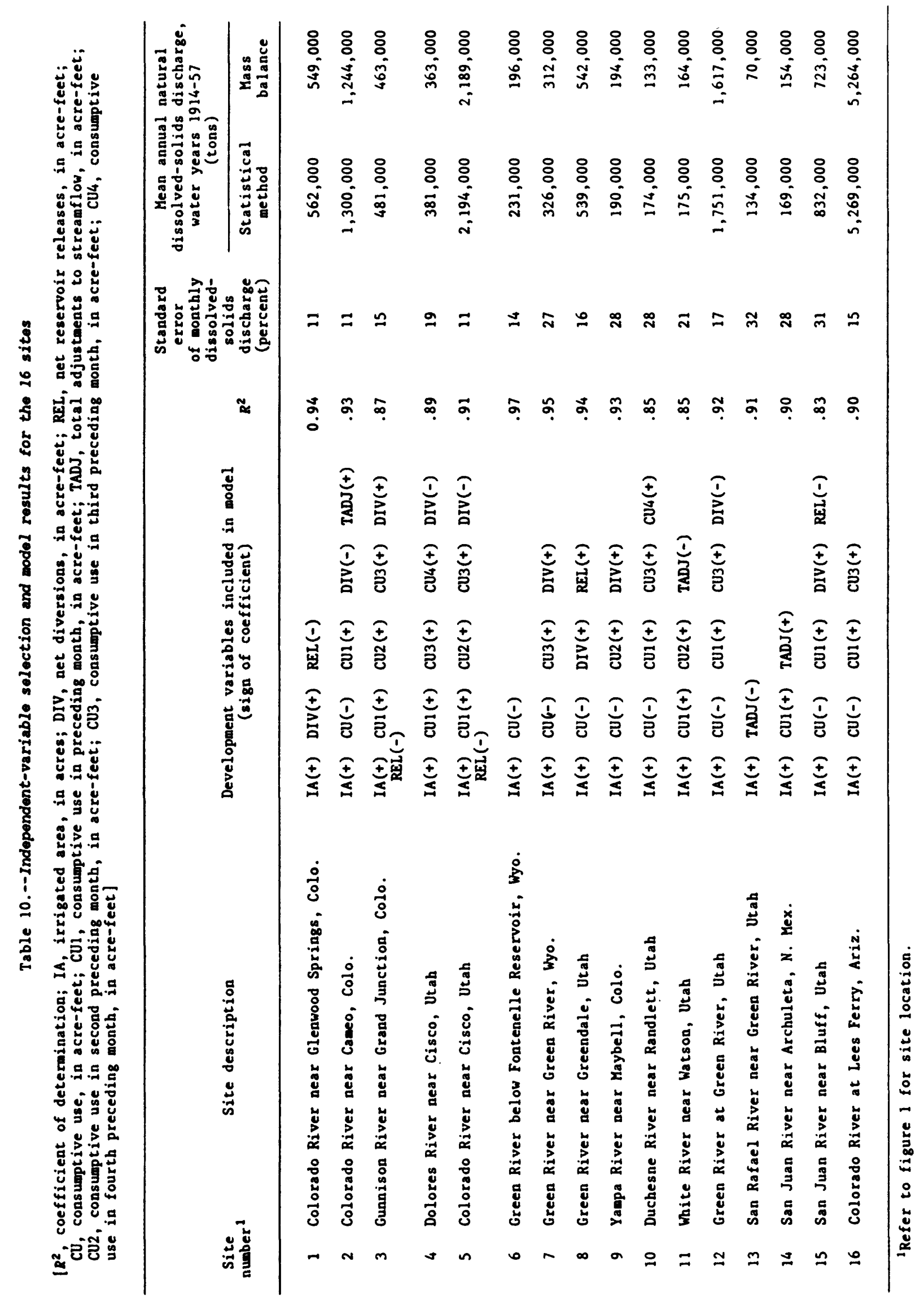


expected signs for the coefficients. However, the models for several sites lid not have the expected sign for net diversion or net reservoir release. At these sites, the net diversion and net reservoir-release terms were not representing the physical occurrence of diversions and reservoir releases in the basin, but may have been accounting for monthly variations in dissolvedsolids discharge caused by some other factor.

The $R^{2}$ values, listed in table 10 , ranged from 0.83 to 0.97 , indicating a strong correlation between actual and estimated dissolved-solids discharge at all 16 sites. The smallest $R^{2}$ values were for site 15, San Juan River near Bluff, Utah; site 11, White River near Watson, Utah; and site 10, Duchesne River near Randlett, Utah. The standard errors ranged from 11 to 32 percent of the actual mean monthly dissolved-solids discharges. The sites having the larger dissolved-solids discharge generally had the smaller standard errors. The largest standard errors occurred for site 13, San Rafael River near Green River, Utah, and site 15, San Juan River near Bluff, Utah. Statistical estimates of mean annual natural dissolved-solids discharge generally were comparable to the mass-balance estimates. At the farthest downstream site, site 16, Colorado River at Lees Ferry, Ariz., the difference was less than 0.1 percent. Differences greater than 10 percent occurred at only four sites: site 15, San Juan River near Bluff, Utah (15 percent); site 6, Green River below Fontenelle Reservoir, Wyo. (18 percent); site 10, Duchesne River near Randlett, Utah (31 percent); and site 13, San Rafael River near Green River, Utah (91 percent).

With the exception of site 15, San Juan River near Bluff, Utah, the sites having the poorest model fit also had the smallest dissolved-solids discharge. The mass-balance estimates of natural dissolved-solids discharge for site 6 , the Green River below Fontenelle Reservoir, Wyo.; site 10, Duchesne River near Randlett, Utah; site 11, White River near Watson, Utah; and site 13, San Rafael River near Green River, Utah, were all less than 200,000 tons per year and, in total, accounted for less than 11 percent of the estimate for site 16, Colorado River at Lees Ferry, Ariz. The sites of most concern were site 10, Duchesne River near Randlett, Utah, and site 13, San Rafael River near Green River, Utah, because the differences between the statistical estimates and mass-balance estimates were so large.

The entire period of record for site 10, Duchesne River near Randlett, Utah, was affected by upstream regulation and transbasin exports from Strawberry Reservoir. However, the net diversion and net reservoir-release variables were not significant in the model for this site. This unexpected result could have been caused by lack of variability in the historical data, which is common at regulated sites. Because the effect of the reservoir is not explicitly considered in the model, estimates of predevelopment conditions could be inaccurate. Iorns and others (1965) also reported that some of the return flows from irrigation in the Duchesne River basin may be bypassing site 10 and entering the Green River directly. Therefore, a linear combination of consumptive use terms from preceding months may not be the best estimator of return flows at the site.

The San Rafael River basin also has a number of diversions that were not included in the model for site 13, San Rafael River near Green River, Utah. 
However, for this site, the accuracy of the model may not be any more questionable than the accuracy of the mass-balance estimate. The San Rafael River alternately has periods of no flow and flash flooding. Studies of other intermittent streams in the Upper Colorado River Basin have indicated that dissolved-solids concentrations fluctuate considerably during storms and from one storm to the next (Shen and others, 1981; Riley and others, 1982a, 1982b). When concentration fluctuates, estimation of long-term dissolved-solids discharge from periodic samples can be inaccurate. Therefore, the large difference between the statistical model and the mass-balance estimates at this site did not necessarily indicate an inaccurate model. Also, the absolute difference was only 1 percent of the mass-balance estimate at the next downstream site, number 16, Colorado River at Lees Ferry, Ariz., so the error at site 13 was inconsequential in contributing to any error in the intervening reach.

Monthly mean natural dissolved-solids concentrations were computed as the quotient of the discharge values reported in table 9 and the monthly mean natural streamflows provided by the U.S. Bureau of Reclamation (written commun., 1983). These concentrations then were plotted (figs. 4-8) to qualitatively determine whether the model results were reasonable. The true natural dissolved-solids concentrations were assumed to plot as a fairly smooth curve having a minimum between May and July during snowmelt, and a maximum between November and March during winter baseflow. In addition, there should not be a pronounced peak in the late summer or early fall. Such a peak has been reported as characteristic of sites affected by irrigation return flows (Moody and Mueller, 1984), and its occurrence in estimates of natural dissolved-solids concentrations would make the estimates questionable.

The curves were similar within subbasins and showed the expected changes in dissolved-solids concentration downstream. Along the Colorado River (fig. 4), concentration increased from site 1 to site 2 (between Glenwood Springs and Cameo, Colo.), which is reasonable because saline springs contribute dissolved solids in this reach. Concentration then decreased between site 2 and site 5 (from Cameo, Colo., to Cisco, Utah), which could be accounted for by the dilution effect of Gunnison River inflow. Concentration continued to decrease between site 5 and site 16 (Cisco, Utah, to Lees Ferry, Ariz.) from September through March, but increased from April through July. This effect could be caused by mixing of the Green River and San Juan River inflows, for which concentration does not vary as much as it does for the Colorado River (figs. 5 and 6 ).

The curves for the Green River (fig. 5) generally indicated a steady increase in dissolved-solids concentration downstream. This increase was expected because the tributary concentrations coming into the Green River were relatively large; therefore, there was no dilution due to inflow. Baseflow concentration at the headwater site 6 , below Fontenelle Reservoir, Wyo., was substantially smaller than that for site 1, Colorado River near Glenwood Springs, Colo. (fig. 4). This difference can be attributed to the large saline springs that occur upstream from site 1 . Dissolved-solids concentrations were similar at the two sites during snowmelt when the effect of the springs was diluted. The concentration curve for site 8 , Green River near Greendale, Utah, is somewhat anomalous. It seems too small for the fall and 


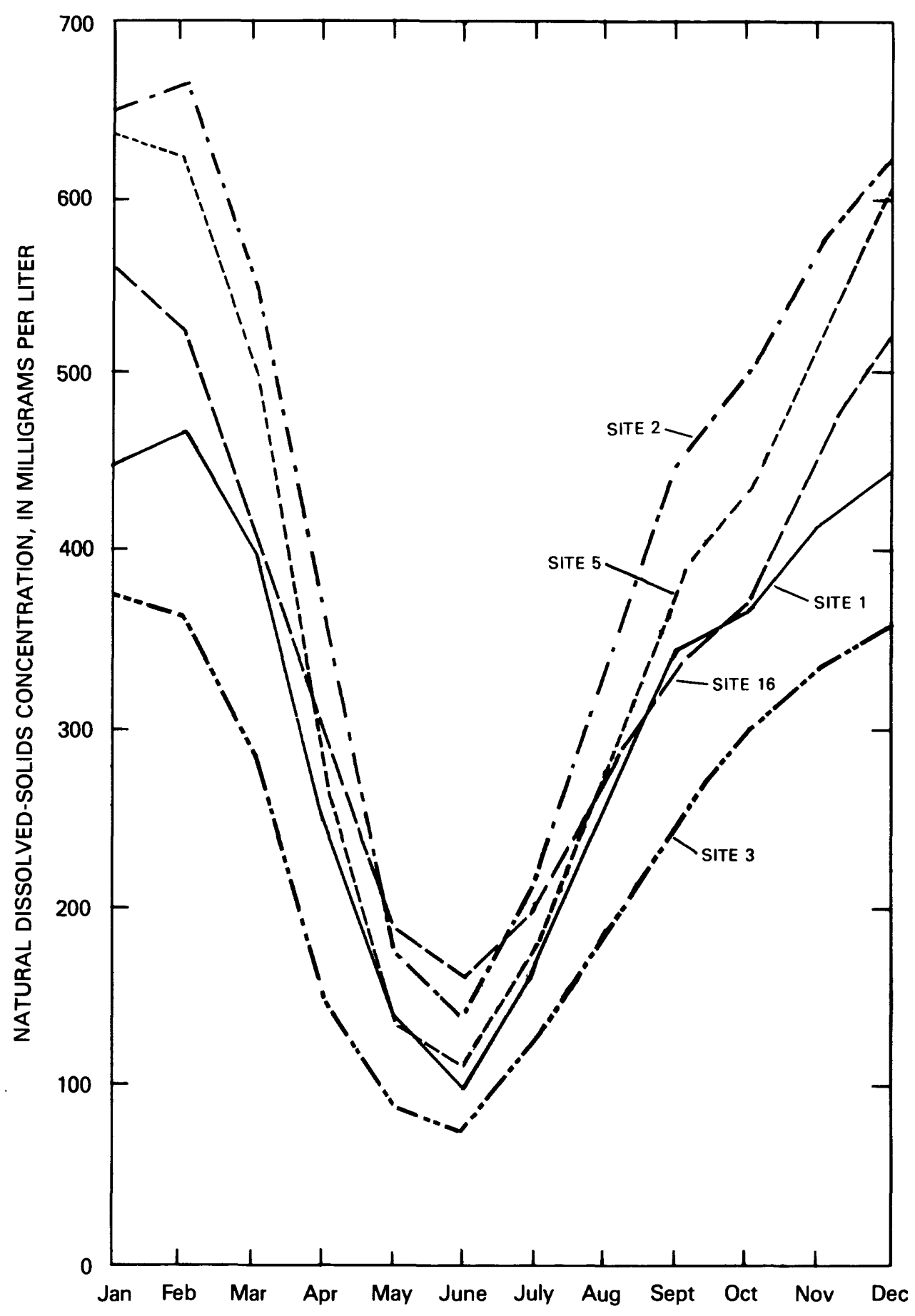

Figure 4.--Monthly mean natural dissolved-solids concentrations for sites along the Colorado River and the Gunnison River. 


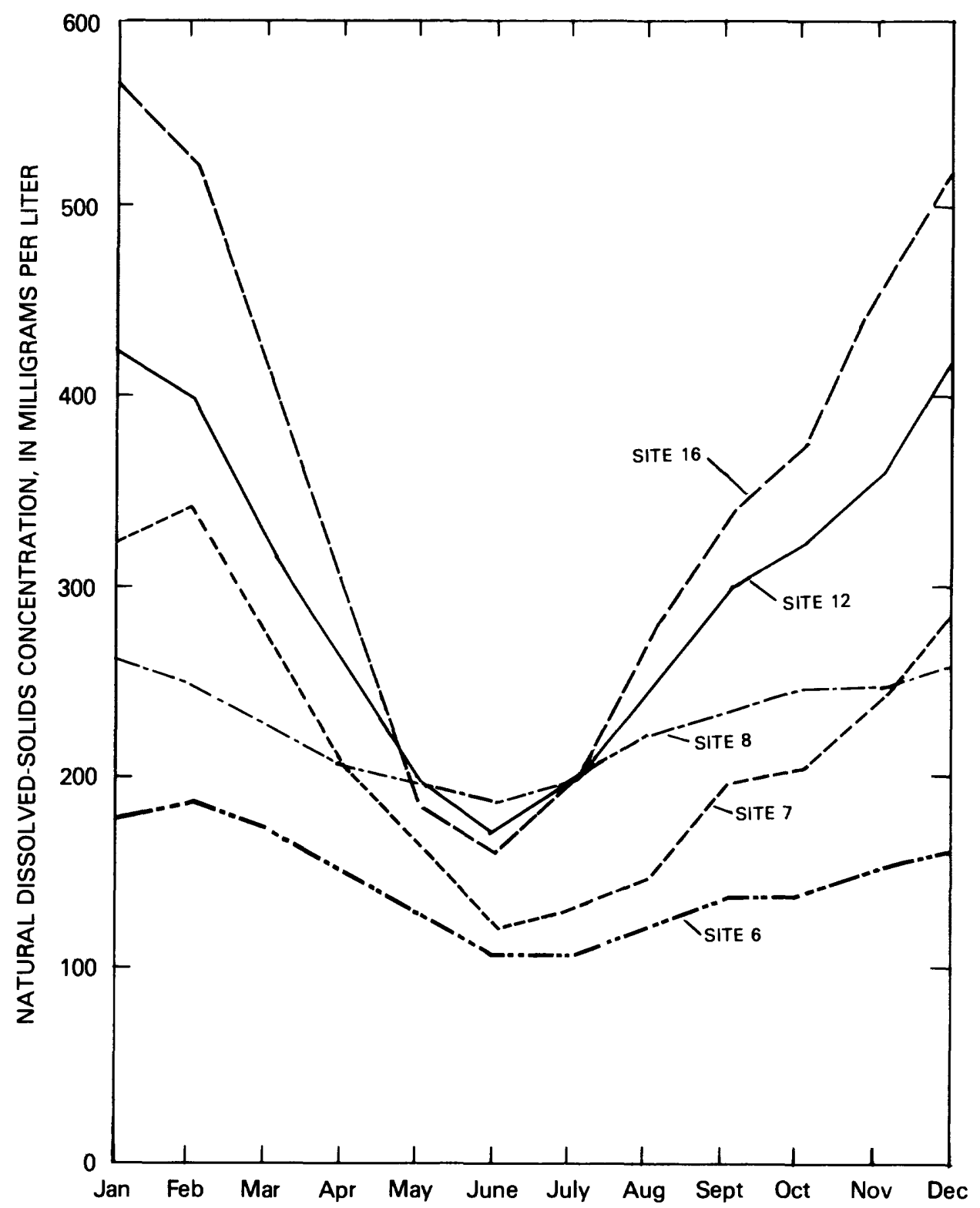

Figure 5.--Monthly mean natural dissolved-solids concentrations for sites along the Green River and the Colorado River at Lees Ferry, Ariz. 


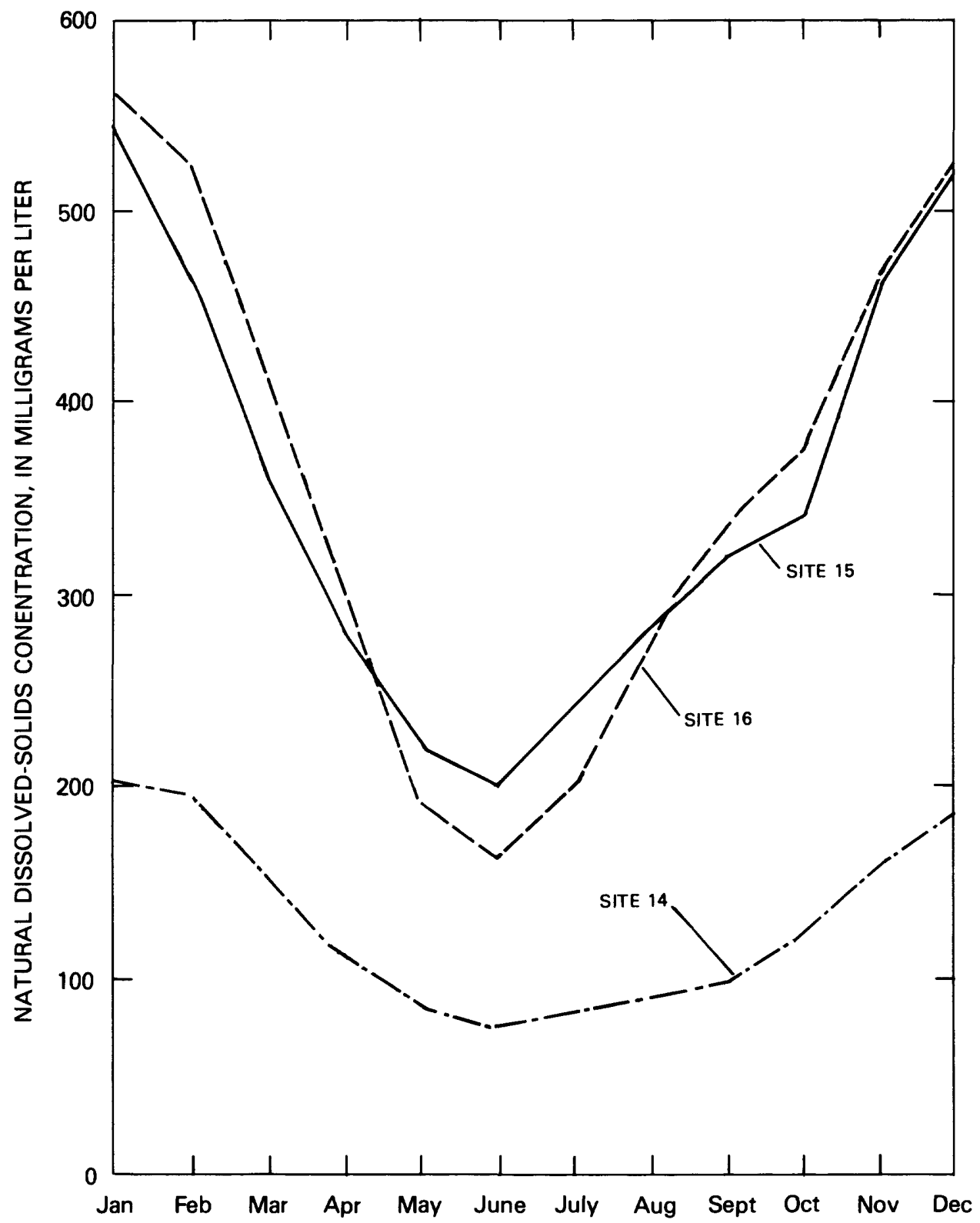

Figure 6.--Monthly mean natural dissolved-solids concentrations for sites along the San Juan River and at the Colorado River at Lees Ferry, Ariz. 


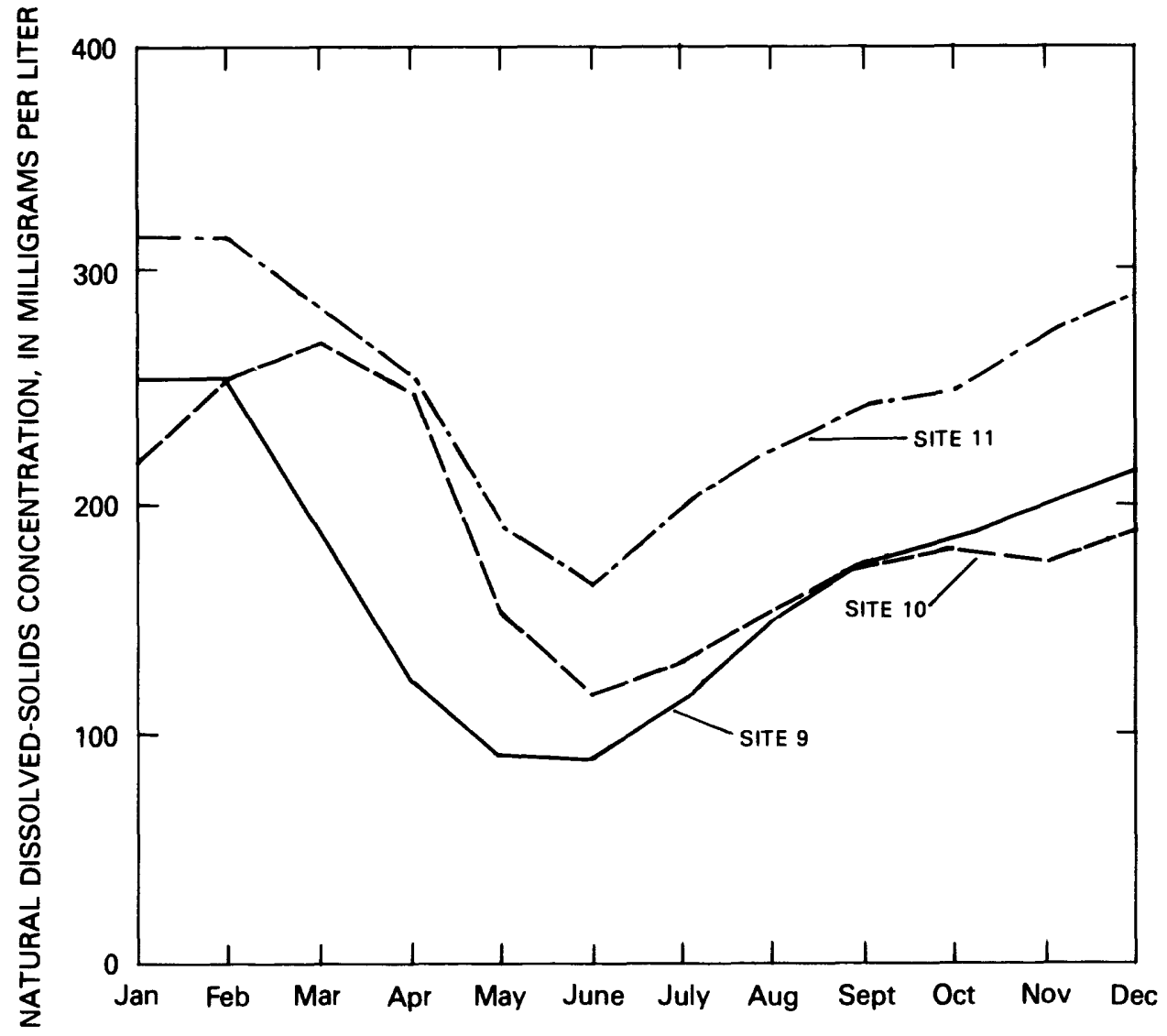

Figure 7.--Monthly mean natural dissolved-solids concentrations for sites along tributaries of the Green River.

winter months and too large for the spring and summer months. This site is downstream from Flaming Gorge Reservoir, and the period of record prior to impoundment is short. The reservoir has decreased the seasonal variability of dissolved-solids concentrations at the site. This effect has not been completely eliminated from the estimates of natural dissolved-solids concentration.

The only other apparent anomaly was for tributaries (figs. 7 and 8 ). Sites 10 and 13, on the Duchesne and the San Rafael Rivers, had a small peak in dissolved-solids concentration during the early autumn, which could be a residual effect of irrigation return flow that was not removed by the modeling procedure. Problems with model fitting previously have been discussed for the sites on both these tributaries. However, the anomalies in the plots were minor, and the problems identified for these sites were not considered substantial. 


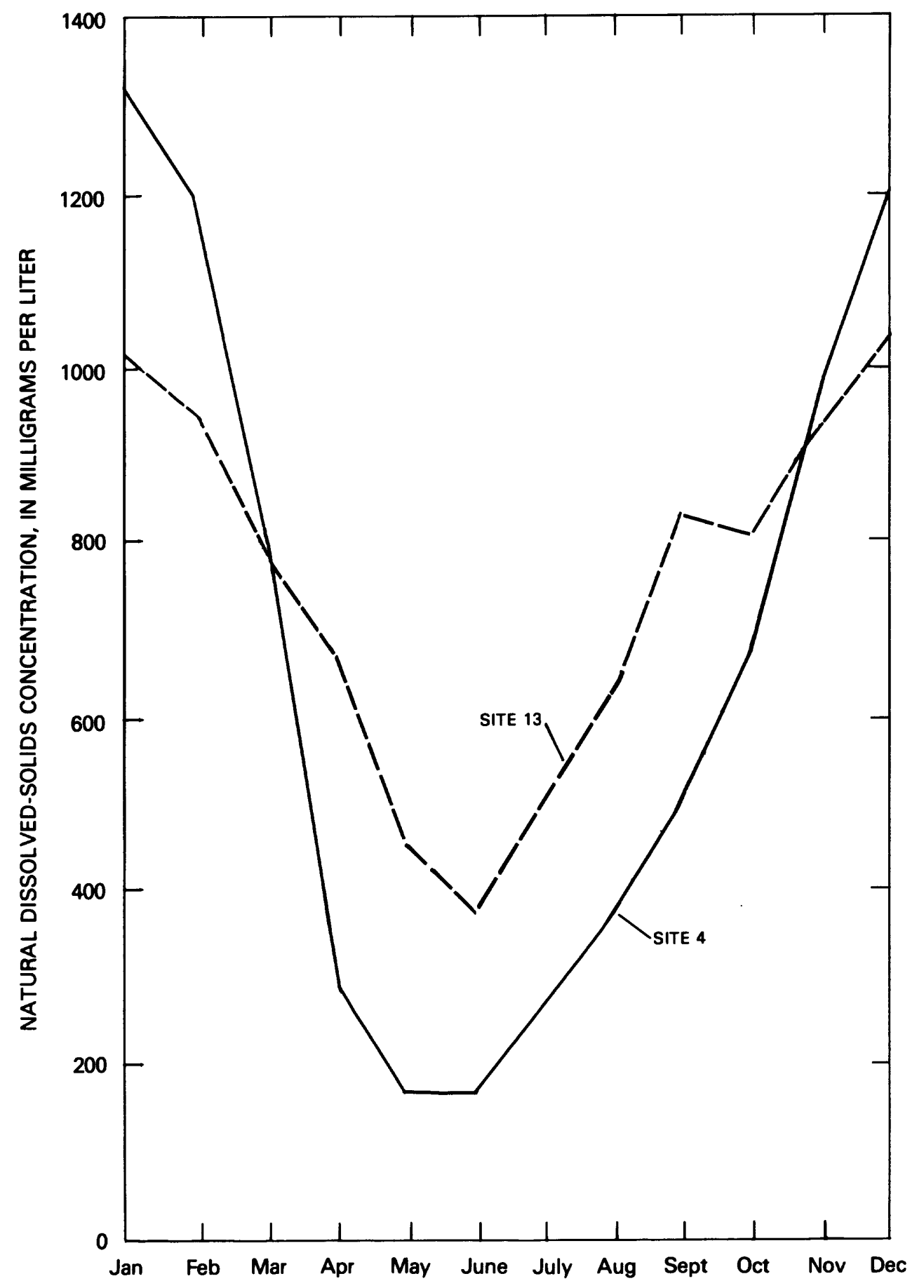

Figure 8.--Monthly mean natural dissolved-solids concentrations for sites along the Dolores and the San Rafael Rivers. 
Model results for downstream sites were evaluated to determine whether the estimated gains or losses of dissolved solids in the intervening reaches were realistic. The downstream site numbers, the corresponding upstream site numbers, the reach drainage area, and the total drainage area above the upstream sites are listed in table 11 . The number of monthly occurrences of increasing or decreasing dissolved-solids discharge and streamflow between the upstream sites and the downstream site also are summarized. Case 1 denotes an increase in both dissolved-solids discharge and streamflow in the reach. Increases generally were expected for large intervening areas that had substantial tributary inflow. Case 2 denotes a decrease of both dissolved-solids discharge and streamflow, and case 3 denotes an increase in discharge and a decrease in streamflow in the reach. Natural losses of streamflow in a reach could be caused by seepage or riparian evapotranspiration. If a reach is losing both dissolved-solids and streamflow (case 2), a part of the dissolvedsolids loss might be associated with water going into bank storage or seeping into ground water. If the streamflow loss primarily is due to evapotranspiration, the dissolved-solids discharge would not be affected and could increase because of inflow (case 3 ). Case 4 represents a decrease in dissolved-solids discharge and an increase in streamflow. This situation is unlikely, although three sites $(5,8$, and 16 ) had a large number of case-4 occurrences. At all these sites, the reach drainage area is small compared to the upstream drainage area. Therefore, the intervening discharge and streamflow are small compared to the total discharge and streamflow at the site. Small errors at either the upstream or downstream sites could cause substantial anomalies in the intervening gains or losses of dissolved solids and streamflow. For all case-4 occurrences, the dissolved-solids discharge loss was well within the standard error for estimated discharge at the downstream site.

For the reach upstream from site 5, Colorado River near Cisco, Utah, all case-4 occurrences were during May through October, indicating potentially larger errors in the predictions for these months. For the reach upstream from site 8, Green River near Greendale, Utah, all of the case-4 occurrences were during September through March. Natural dissolved-solids concentrations at this site seemed unreasonably small during this same period (fig. 5). The case-4 occurrences are additional evidence that these small concentrations are indeed unreasonable.

\section{VERIFICATION OF THE STATISTICAL MODEL}

All the data available for determining natural dissolved-solid discharge in the Upper Colorado River Basin were collected after most of the irrigation development in the basin had already occurred; therefore, no true verification of the statistical-model estimates of natural dissolved-solids discharge was possible. A standard split-sample analysis would verify only the model's ability to estimate historical discharge. The mass-balance estimates could not be used for verification of the statistical model because they were incorporated into the calibration data. 


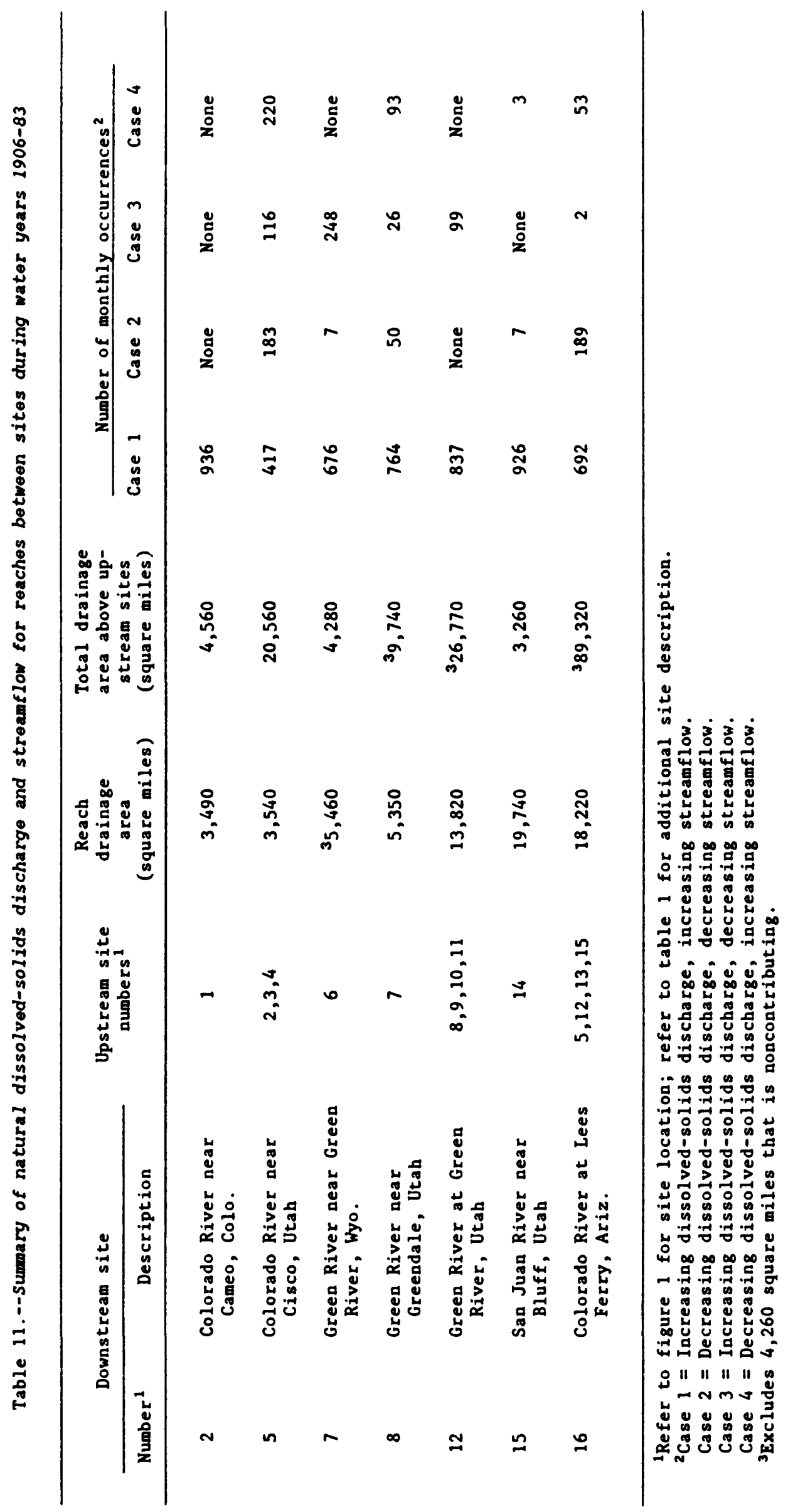


There was a limited quantity of data available from a survey made during water years 1905-6 (Stabler, 1911) that was not included in the calibration data. Because irrigation was less extensive at the time of this survey, these data could be used to test extrapolation outside the range of the development data used to calibrate the models. Samples were collected at only 1 of the 16 sites used in the present study: site 7, Green River near Green River, Wyo. However, two other sampling locations were near enough to provide adequate comparisons. These two locations were on the Colorado River (called the Grand River at the time of the 1905-6 survey) near Palisade, Colo., a few river miles downstream from site 2, Colorado River near Cameo, Colo., and on the Gunnison River near Whitewater, Colo., in approximately the same location as site 3, Gunnison River near Grand Junction. In addition, data collected during the 1905-6 survey from a sampling location on the Green River near Jensen, Utah, downstream from site 8, Green River near Greendale, Utah, and site 9, Yampa River near Maybe11, Colo., could be used to provide a comparison with the sum of the estimated dissolved-solids discharges from these two sites. The 1905-6 sampling locations used in the model verification are shown in figure 1.

Verification estimates of historical dissolved-solids discharge were computed using 1906 values of the development variables and monthly streamflow from the 1905-6 survey. The results are plotted in figure 9. Model estimates matched the measured values accurately for dissolved-solids discharges less than 200,000 tons per month, but not as accurately for greater discharges. The best correlation was for data from site 7, Green River near Green River, Wyo., but even at this site, the largest discharge value was not estimated as accurately as the others. In general, the models seem more accurate for periods of low streamflow, when development has a greater effect on dissolvedsolids discharge, and less accurate for snowmelt-runoff periods, when streamflow and dissolved-solids discharge are both large and the effect of development is relatively smaller. The model may be giving the development variables too much influence during snowmelt-runoff periods, causing natural discharge to be underestimated. Also, because the models are calibrated on logrithmic transformations of the data, real error is proportionate to the estimated value; therefore larger estimates have larger errors.

\section{SUMMARY}

A statistical method was developed to estimate monthly natural dissolved-solids discharge at selected sites in the Upper Colorado River Basin. The method used weighted least-squares regression to fit a model of dissolved-solids discharge as a function of streamflow and several variables representing water-resources development in the basin. After the model had been calibrated for an individual site, the development variables were assigned a value of zero to yield a relation between dissolved-solids discharge and streamflow for predevelopment conditions upstream from the site. Natural dissolved-solids discharge was calculated using this relation and estimates of natural streamflow provided by the U.S. Bureau of Reclamation. 


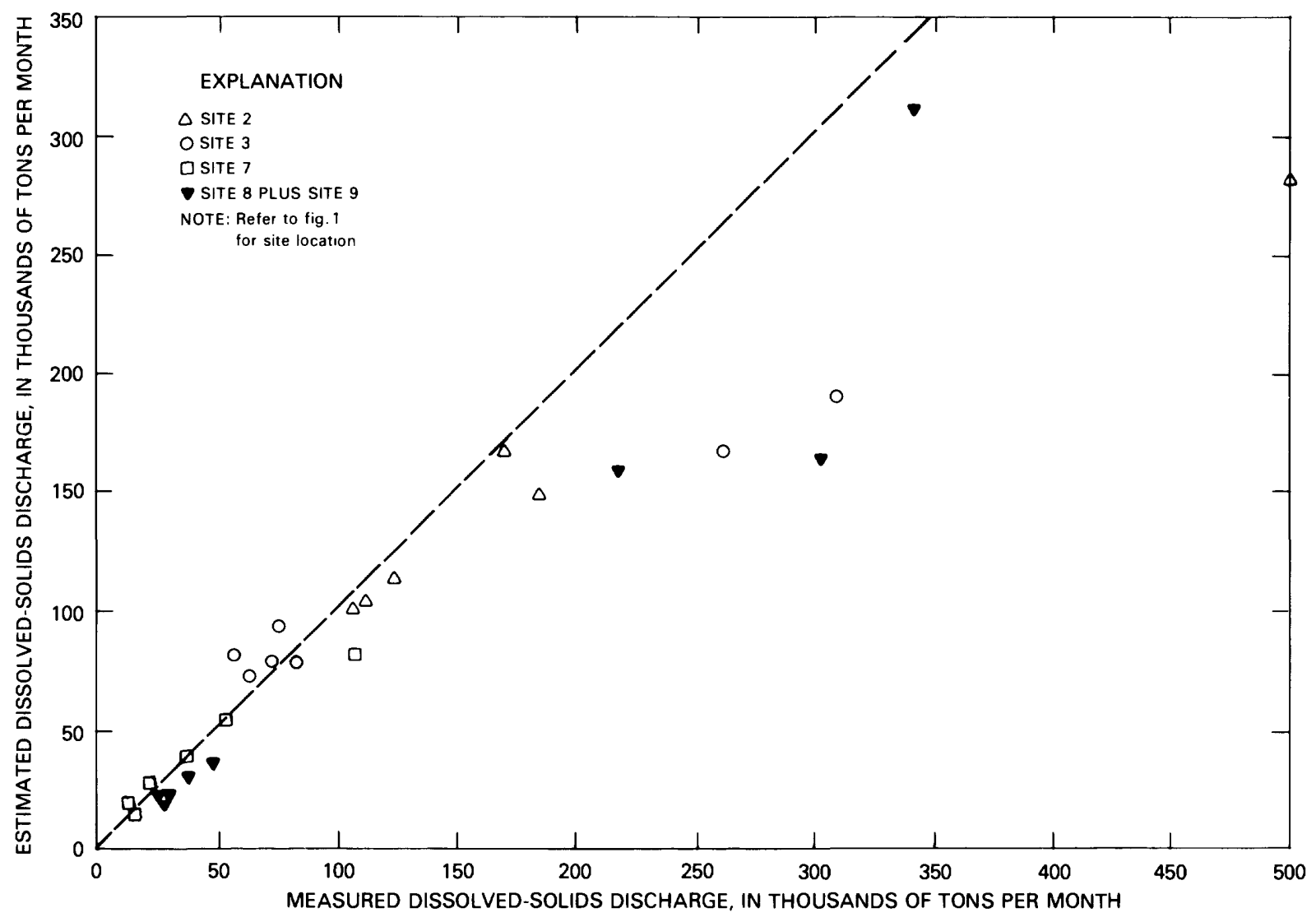

Figure 9.--Comparison of estimated and measured dissolved-solids discharge for samples collected during water years 1905-6. 
Problems were encountered with the method because of the necessity to extrapolate back to predevelopment conditions. Most of the development in the basin was completed prior to the initiation of water-quality sampling. Therefore, the period of record available for model calibration did not include a considerable range of values for the development variables. To increase this range, estimates of mean annual natural dissolved-solids discharge, computed by mass balance, were separated into monthly values, which were added to the calibration data. The extrapolation problems were alleviated, but no independent estimates of natural dissolved-solids discharge remained to verify the model results. These results were determined to be sensitive to variations in the mass-balance values.

Another problem with the models was that the coefficients for the development variables did not always have the expected sign, which could have been caused by inadequate representation of water-resources development effects. Irrigation return flows, in particular, could have been inaccurately represented in the models. These flows had to be estimated based on the consumptive use in previous months because no actual data were available for return-flow volume or distribution. Reservoir regulation also may have been inaccurately represented because of inadequate data.

Despite these problems, the model-derived values were within acceptable limits. The models preserved the values of mean annual natural dissolvedsolids discharge that were obtained from mass-balance estimates. The monthly distributions of natural dissolved-solids discharge and concentration were realistic. With few exceptions, the intervening gains and losses of dissolved solids between sites also were realistic. Potential anomalies were identified in the estimates of natural dissolved-solids discharge for several sites. The most serious was for site 8 , Green River near Greendale, Utah, for which natural discharge seems to have been underestimated for the fall and winter months and overestimated for the spring and summer months.

A limited verification was performed using data collected during water years 1905-6, when development was less extensive. The models for five sites were tested. All five models seemed accurate for small dissolved-solids discharge, but they underestimated larger discharge. 
DeLong, L.L., 1977, An analysis of salinity in streams of the Green River Basin, Wyoming: U.S. Geological Survey Water-Resources Investigations 77-103, $32 \mathrm{p}$.

Follansbee, Robert, 1929, Upper Colorado River and its utilization: U.S. Geological Survey Water-Supply Paper 617, $394 \mathrm{p}$.

Ha11, F.R., 1970, Dissolved solids-discharge relationships 1--Mixing models: Water Resources Research, v. 5, no. 3, p. 845-850. 1971, Dissolved solids-discharge relationships 2--Applications to field data: Water Resources Research, v. 7, no. 3, p. 591-601.

Hutchison, N.E., compiler, 1975, WATSTORE--National water-quality data storage and retrieval system of the U.S. Geological Survey--User's guide: U.S. Geological Survey Open-File Report 75-426, 791 p.

Iorns, W.V., Hembree, C.H., and Oakland, G.L., 1965, Water resources of the Upper Colorado River Basin--Technical report: U.S. Geological Survey Professional Paper 441, 370 p.

Kircher, J.E., Dinicola, R.S., and Middelburg, R.F., 1984, Trend analysis of salt load and evaluation of the frequency of water-quality measurements for the Gunnison River in Colorado and the Dolores River in Colorado and Utah: U.S. Geological Survey Water-Resources Investigations Report $84-4048,69 \mathrm{p}$.

Lane, W.L., 1975, Extraction of information on inorganic water quality: Fort Collins, Colorado State University, Hydrology Paper 73, 74 p.

LaRue, E.C., 1916, Colorado River and its utilization: U.S. Geological Survey Water-Supply Paper 395, 231 p.

Liebermann, T.D., Middelburg, R.M., and Irvine, S.A., 1987, User's manual for estimation of dissolved-solids concentrations and loads in surface water: U.S. Geological Survey Water-Resources Investigations Report 86-4124, $51 \mathrm{p}$.

Liebermann, T.D., Mueller, D.K., Kircher, J.E., and Choquette, A.F., 1988, Chacteristics and trends of streamflow and dissolved solids in the Upper Colorado River Basin, Arizona, Colorado, New Mexico, Utah, and Wyoming: U.S. Geological Survey Open-File Report 87-568, 99 p.

Liebermann, T.D., and Nordlund, B.D., 1988, Estimates of dissolved solids and major dissolved constituents for 70 streamflow-gaging stations in the Upper Colorado River Basin: U.S. Geological Survey Open-File Report 87-547, $608 \mathrm{p}$.

Loftis, J.C., 1983, Statistical methods for evaluating the effectiveness of the Grand Valley salinity control program, in Shafique, M.S.; Skogerboe, G.V., Loftis, J.C.; Sheitlin, S.M.; Rude, P.H.; Hatami, Bahman; and Barsten, George, Monitoring and evaluation of on-farm improvements in the Grand Valley salinity control project during the 1982 irrigation season: Denver, U.S. Soil Conservation Service, $130 \mathrm{p}$.

Miller, D.M., 1984, Reducing transform bias in curve fitting: The American Statistician, v. 38, no. 2, p. 124-126.

Montgomery, D.C., and Peck, E.A., 1982, Introduction to linear regression analysis: New York, John Wiley and Sons, 504 p.

Moody, C.D., and Mueller, D.K., 1984, Surface-water quality of the Colorado River system--Historical trends in concentration, load, and mass fraction of inorganic solutes: U.S. Bureau of Reclamation Report REC-ERC-84-9, $60 \mathrm{p}$. 
Mueller, D.K., and Moody, C.D., 1984, Historical trends in concentration and load of major ions in the Colorado River system, in French, R.H., ed., Salinity in watercourses and reservoirs: Boston, Butterworth Publishers, p. 181-192.

Riley, J.P., Chadwick, D.G., Jr., Dixon, L.S., James, L.D., Grenney, W.J., and Israelson, E.K., 1982a, Salt uptake in natural channels traversing Mancos Shales in the Price River basin, Utah: Logan, Utah State University, Water Resources Planning Series UWRL/P-82/02, 194 p.

Riley, J.P., Israelson, E.K., McNeill, W.N., and Peckins, Brian, 1982b, Potential of water and salt yields from surface runoff on public lands in the Price River basin: Logan, Utah State University, Water Resources Planning Series UWRL/P-82/01, $94 \mathrm{p}$.

SAS Institute Inc., 1985, SAS user's guide--Statistics, version 5 edition: Cary, N.C., 956 p.

Shen, H.W., Laronne, J.B., Enck, E.D., Sunday, G., Tanji, K.K., Whittig, L.D., and Biggar, J.W., 1981, Role of sediment in non-point source salt loading within the Upper Colorado River Basin: Fort Collins, Colorado State University, Water Resources Research Institute Report 107, 213 p.

Stabler, Herman, 1911, Some stream waters of the Western United States: U.S. Geological Survey Water-Supply Paper 274, $188 \mathrm{p}$.

Steele, T.D., 1976, A bivariate-regression model for estimating chemical composition of streamflow or groundwater: Hydrological Sciences Bulletin, v. 21, no. 1, p. 149-161.

U.S. Bureau of Reclamation, 1983, Colorado River Water Quality Improvement Program, 1983 status report: Denver, Colorado, $126 \mathrm{p}$. 1985, Colorado River simulation system: Denver, 55 p. plus appendices.

U.S. Department of the Interior, 1985, Quality of water--Colorado River Basin: Progress Report 12, Salt Lake City, U.S. Bureau of Reclamation, $220 \mathrm{p}$.

U.S. Environmental Protection Agency, 1971, The minera1 quality problem in the Colorado River Basin: Washington, D.C., 61 p. plus appendices.

U.S. Soil Conservation Service, 1970, Irrigation water requirements: U.S. Soil Conservation Service Technical Release 21, $88 \mathrm{p}$.

Wooley, R.R., 1930, The Green River and its utilization: U.S. Geological Survey Water-Supply Paper 618, $456 \mathrm{p}$. 
SUPPLEMENTAL INFORMATION 
Table 12.--Mass balance for site 1, water-quality station 09071100 Colorado River near Glenwood Springs, Colo., for water years $1914-57^{1}$

$$
\text { [---, no data] }
$$

\begin{tabular}{lcccc}
\hline Mass-balance component & $\begin{array}{c}\text { Drainage } \\
\text { area } \\
\text { (square } \\
\text { miles) }\end{array}$ & $\begin{array}{c}\text { Irrigated } \\
\text { area } \\
\text { (acres) }\end{array}$ & $\begin{array}{c}\text { Mean annual } \\
\text { dissolved- } \\
\text { streamflow } \\
\text { (acre-feet) }\end{array}$ & $\begin{array}{c}\text { solids } \\
\text { discharge } \\
\text { (tons) }\end{array}$ \\
\hline
\end{tabular}

Historical conditions

Colorado River near Glenwood

Springs, Colo.:- 4,560 83,700 $1,683,000 \quad 639,200$

Adjustments for development

Irrigation:

Fraser River basin-

285

10,200

$(+) 8,650$

$(-) 1,440$

Sulpher Springs, excluding the

Fraser River basin-........... 497

Troublesome Creek basin-.......... 178

178

5,500

8,000

$(+) 5,500$

$(+) 5,600$

60,000

$2(+) 60,000$

$(-) 6,200$

$(-) 3,850$

Remaining drainage area--......- 3,600

Transbasin diversions:

Grand River ditch, Eureka ditch, Alva B. Adams tunnel, Berthoud Pass ditch, Moffat Water tunnel, Jones Pass tunnel, Hoosier Pass tunnel, Boreas Pass ditch, Columbine ditch, Ewing ditch, and Wurtz ditch--...-

\section{Natural conditions}

Colorado River near Glenwood Springs,

Colo.-- River near Glenood Springs,

Estimated mean annual natural dissolved-solids concentration for water years 1914-57: 190 milligrams per liter

\footnotetext{
${ }^{1}$ Based on Iorns and others (1965).

${ }^{2}$ Based on a consumptive rate of 1 acre-foot per acre of irrigated land.
} 
Table 13.--Mass balance for site 3, streamflow-gaging station 09152500 Gunnison River near Grand Junction, Colo., for water years 1914-57'

$$
[-., \text { no data }]
$$

\begin{tabular}{lcccc}
\hline Mass-balance component & $\begin{array}{c}\text { Drainage } \\
\text { area } \\
\text { (square } \\
\text { miles) }\end{array}$ & $\begin{array}{c}\text { Irrigated } \\
\text { area } \\
\text { (acres) }\end{array}$ & $\begin{array}{c}\text { Mean annual } \\
\text { streamflow } \\
\text { (acre-feet) }\end{array}$ & $\begin{array}{c}\text { Mean annual } \\
\text { dissolved- } \\
\text { solids } \\
\text { discharge } \\
\text { (tons) }\end{array}$ \\
\hline
\end{tabular}

\section{Historical conditions}

Gunnison River near Grand Junction, Colo.

$269,400 \quad 1,884,000$

$1,519,000$

Adjustments for development

Irrigation:

Drainage area upstream from the Gunnison tunnel-..............

Drainage area downstream from the Gunnison tunnel-............... 3,963

$\begin{array}{rrrr}3,965 & 74,400 & (+) 348,200 & 2(-) 35,700 \\ 3,963 & 195,000 & & 2(-) 1,048,750\end{array}$

Municipal and industrial:-_._._...-. -.

Transbasin diversions:

Larkspur ditch, Taber ditch-...-.-. -.-

$\begin{array}{r}(+) 2,600 \quad(-) 3,800 \\ -\quad(+) 300 \quad{ }^{3}(+) 25 \\ \hline\end{array}$

\section{Natural conditions}

Gunnison River near Grand Junction, Colo.

$-\cdot$

Estimated mean annual natural dissolved-solids concentration for water years 1914-57: 140 milligrams per liter

${ }^{1}$ Based on Iorns and others (1965).

${ }^{2}$ Corrected for error in Iorns and others (1965), table 22, p. 168.

${ }^{3}$ Based on a weighted average concentration of 60 milligrams per liter; Iorns and others (1965), p. 141 . 
Table 14.--Mass balance for site 4, streamflow-gaging station 09180000 Dolores River near Cisco, Utah, for water years $1914-57^{1}$

$$
\text { [--, no data] }
$$

\begin{tabular}{|c|c|c|c|c|}
\hline Mass-balance component & $\begin{array}{l}\text { Drainage } \\
\text { area } \\
\text { (square } \\
\text { miles) }\end{array}$ & $\begin{array}{l}\text { Irrigated } \\
\text { area } \\
\text { (acres) }\end{array}$ & $\begin{array}{l}\text { Mean annual } \\
\text { streamflow } \\
\text { (acre-feet) }\end{array}$ & $\begin{array}{l}\text { Mean annual } \\
\text { dissolved- } \\
\text { solids } \\
\text { discharge } \\
\text { (tons) }\end{array}$ \\
\hline \multicolumn{5}{|l|}{ Historical conditions } \\
\hline Dolores River near Cisco, Utah-....-...- & $-4,580$ & 37,100 & 681,000 & 460,200 \\
\hline \multicolumn{5}{|l|}{ Adjustments for development } \\
\hline \multirow{2}{*}{$\begin{array}{l}\text { Irrigation: } \\
\text { San Miguel River basin between } \\
\text { Placerville and Naturita, Colo.-- } \\
\text { Remaining drainage area-- } \\
\text { Transbasin diversions: } \\
\text { Export to the San Juan River basin-- }\end{array}$} & $\begin{array}{r}772 \\
-\quad 3,808\end{array}$ & $\begin{array}{l}15,000 \\
22,100\end{array}$ & $\begin{array}{l}2(+) 30,000 \\
2(+) 44,200\end{array}$ & $\begin{array}{l}(-) 45,850 \\
(-) 71,300\end{array}$ \\
\hline & --- & -- & $\underline{(+) 100,000}$ & $\underline{(+) 17,000}$ \\
\hline \multicolumn{5}{|l|}{ Natural conditions } \\
\hline Dolores River near Cisco, Utah-......... & --- & -- & 855,200 & 360,050 \\
\hline \multicolumn{5}{|c|}{$\begin{array}{l}\text { Estimated mean annual natural dissolved-solids concentration for water years 1914-57: } \\
310 \text { milligrams per liter }\end{array}$} \\
\hline
\end{tabular}

${ }^{1}$ Based on Iorns and others (1965).

${ }^{2}$ Based on a consumptive rate of 2 acre-feet per acre of irrigated land. 
Table 15.--Mass balance for site 5, streamflow-gaging station 09180500 Colorado River near Cisco, Utah, for water years $1914-57^{1}$

$$
\text { [---, no data] }
$$

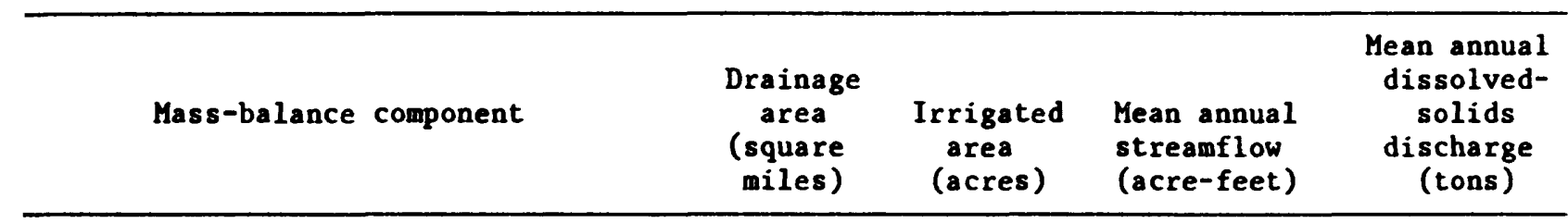

\section{Historical conditions}

Colorado River near Cisco, Utah------ 24,100 577,700 5,634,000 4,120,000

Adjustments for development

Irrigation: Intervening drainage area--.---.-- $3,542 \quad 107,800 \quad 2(+) 118,580 \quad(-) 444,100$

Effects in upstream areas:

Colorado River near Cameo, Colo.--- $8,050 \quad 163,400 \quad 1(+) 545,220 \quad(-) 357,910$

Gunnison River near Grand Junction,

Colo.

269,400

$(+) 351,100$

$(-) 1,088,225$

Dolores River near Cisco, Utah-_-_--- 4,580

37,100

$(+) 174,200$

$(-) 100,150$

\section{Natural conditions}

Colorado River near Cisco, Utah-...-.

$--$

$--$

$6,823,100$

$2,129,615$

Estimated mean annual natural dissolved-solids concentration for water years 1914-57: 230 milligrams per liter

${ }^{1}$ Based on Iorns and others (1965).

${ }^{2}$ Based on a consumptive rate of 1.1 acre-feet per acre of irrigated land. 
Table 16.--Mass balance for site 6, streamflow-gaging station 09211200 Green River below Fontenelle Reservoir, Wyo., for water years $1914-57^{1}$

$$
\text { [--., no data] }
$$

\begin{tabular}{lcccc}
\hline Mass-balance component & $\begin{array}{c}\text { Drainage } \\
\text { area } \\
\text { (square } \\
\text { miles) }\end{array}$ & $\begin{array}{c}\text { Irrigated } \\
\text { area } \\
\text { (acres) }\end{array}$ & $\begin{array}{c}\text { Mean annual } \\
\text { streamflow } \\
\text { (acre-feet) }\end{array}$ & $\begin{array}{c}\text { dissolved- } \\
\text { solids } \\
\text { (tons) }\end{array}$ \\
\hline
\end{tabular}

Historical conditions

Green River below Fontenelle

Reservoir, Wyo.-

Adjustments for development

Irrigation:

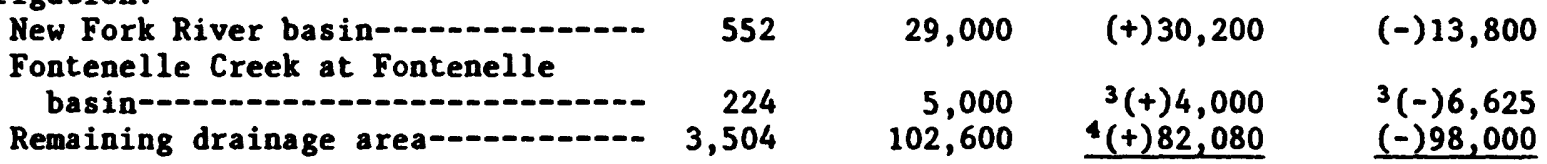

\section{Natural conditions}

Green River below Fontenelle

Reservoir, Wyo.:- $1,331,760 \quad 196,025$

Estimated mean annual natural dissolved-solids concentration for water years 1914-57: 110 milligrams per liter

${ }^{1}$ Based on Iorns and others (1965).

2Excludes approximately 86 square miles of drainage area.

${ }^{3}$ Adjusted from Iorns and others (1965) to account for additional drainage area included in the basin.

${ }^{4}$ Based on a consumptive rate of 0.8 acre-foot per acre of irrigated land. 
Table 17.--Mass balance for site 7, streamflow-gaging station 09217000 Green River near Green River, Wyo., for water years 1914-571

$$
\text { [---, no data] }
$$

\begin{tabular}{lcccc}
\hline Mass-balance component & $\begin{array}{c}\text { Drainage } \\
\text { area } \\
\text { (square } \\
\text { miles) }\end{array}$ & $\begin{array}{c}\text { Irrigated } \\
\text { area } \\
\text { (acres) }\end{array}$ & $\begin{array}{c}\text { Mean annual } \\
\text { dissolved- } \\
\text { streamflow } \\
\text { (acre-feet) }\end{array}$ & $\begin{array}{c}\text { solids } \\
\text { (tons) }\end{array}$ \\
\hline
\end{tabular}

Historical conditions

Green River near Green River, Wyo..-- $29,740 \quad 151,600 \quad 1,305,000 \quad 504,000$

Adjustments for development

Irrigation:

Big Sandy River basin ${ }^{3}$ between

Farson and Eden, Wyo.:-...-. $620 \quad 11,000 \quad{ }^{4}(+) 14,300 \quad(-) 49,000$

Remaining drainage area--.....-.- 4,840 $\quad 4,000 \quad 4(+) 5,200 \quad 5(-) 17,800$

Effects in upstream areas:

Green River below Fontenelle

Reservoir, Wyo..-........ $4,280 \quad 136,600 \quad(+) 116,280 \quad(-) 118,425$

Natural conditions

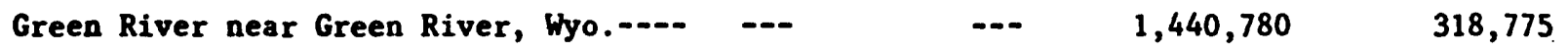

Estimated mean annual natural dissolved-solids concentration for water years 1914-57:

165 milligrams per liter

\footnotetext{
${ }^{1}$ Based on Iorns and others (1965).

${ }^{2}$ Does not include 4,260 square miles, which is noncontributing.

${ }^{3}$ Referred to as Big Sandy Creek in Iorns and others (1965).

'Based on a consumptive rate of 1.3 acre-feet per acre of irrigated land estimated by the Upper Colorado River Basin Compact Commission (Iorns and others, 1965).

5 Based on an added dissolved-solids load of 4.45 tons per acre of irrigated land.
} 
Table 18.--Mass balance for site 8 , streamflow-gaging station 09234500 Green River near Greendale, Utah, for water years 1914-57'

$$
[\cdots, \text { no data }]
$$

\begin{tabular}{lcccc}
\hline Mass-balance component & $\begin{array}{c}\text { Drainage } \\
\text { area } \\
\text { (square } \\
\text { miles) }\end{array}$ & $\begin{array}{c}\text { Irrigated } \\
\text { area } \\
\text { (acres) }\end{array}$ & $\begin{array}{c}\text { Mean annual } \\
\text { streamflow } \\
\text { (acre-feet) }\end{array}$ & $\begin{array}{c}\text { annual } \\
\text { discolived- } \\
\text { solids } \\
\text { (tons) }\end{array}$ \\
\hline
\end{tabular}

\section{Historical conditions}

Green River near Greendale, Utah--.-- $15,090 \quad 2251,000 \quad 1,645,000 \quad 847,400$

Adjustments for development

Irrigation:

Blacks Fork basin upstream from

Muddy Creek-.......................... $575 \quad 59,500$

Hams Fork basin-................ $170 \quad 4,000$

$3(+) 50,575$

$(-) 52,800$

4,000 $\quad 3(+) 3,400$

$(-) 1,200$

Remaining drainage area-............... 4,605

35,900

${ }^{3}(+) 30,515$

$(-) 77,875$

Effects in upstream areas:

Green River near Green River, Wyo.-- $9,740 \quad 151,600 \quad \underline{(+) 135,780} \quad \underline{(-) 185,225}$

Natural conditions

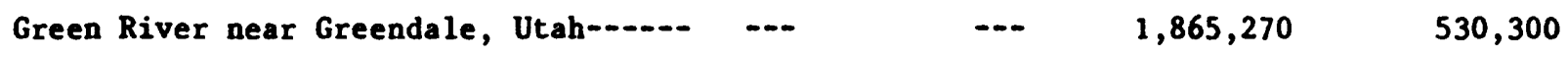

Estimated mean annual natural dissolved-solids concentration for water years 1914-57:

210 milligrams per liter

${ }^{1}$ Based on Iorns and others (1965).

${ }^{2}$ Irrigated acreage data from the U.S. Bureau of Reclamation (written commun., 1983 ).

${ }^{3}$ Based on a consumptive use rate of 0.85 acre-foot per acre. 
Table 19.--Mass balance for site 9, streamflow-gaging station 09251000 Yampa River near Maybe11, Colo., for water years 1914-57 ${ }^{1}$

$$
\text { [---, no data] }
$$

\begin{tabular}{|c|c|c|c|c|}
\hline Mass-balance component & $\begin{array}{l}\text { Drainage } \\
\text { area } \\
\text { (square } \\
\text { miles) }\end{array}$ & $\begin{array}{l}\text { Irrigated } \\
\text { area } \\
\text { (acres) }\end{array}$ & $\begin{array}{l}\text { Mean annual } \\
\text { streamflow } \\
\text { (acre-feet) }\end{array}$ & $\begin{array}{c}\text { Mean annual } \\
\text { dissolved- } \\
\text { solids } \\
\text { discharge } \\
\text { (tons) }\end{array}$ \\
\hline
\end{tabular}

\section{Historical conditions}

Yampa River near Maybell, Colo.....- 3,410 $\quad 51,300 \quad 1,152,000 \quad 218,800$

Adjustments for development

Irrigation:

Yampa River basin at Steamboat $\begin{array}{lrrrr}\text { Springs, Colo.- } & 604 & 22,000 & (+) 17,600 & (-) 3,300 \\ & & \end{array}$

Natural conditions

Yampa River near Maybell, Colo....... -.. $\quad \cdots \quad \cdots \quad 1,192,960 \quad 188,940$

Estimated mean annual natural dissolved-solids concentration for water years 1914-57: 115 milligrams per liter

${ }^{1}$ Based on Iorns and others (1965). 
Table 20.--Mass balance for site 10, streamflow-gaging station 09302000 Duchesne River near Randlett, Utah, for water years $1914-57^{1}$

$$
\text { [---, no data] }
$$

\begin{tabular}{|c|c|c|c|c|}
\hline Mass-balance component & $\begin{array}{l}\text { Drainage } \\
\text { area } \\
\text { (square } \\
\text { miles) }\end{array}$ & $\begin{array}{c}\text { Irrigated } \\
\text { area } \\
\text { (acres) }\end{array}$ & $\begin{array}{l}\text { Mean annual } \\
\text { streamflow } \\
\text { (acre-feet) }\end{array}$ & $\begin{array}{l}\text { Mean annual } \\
\text { dissolved- } \\
\text { solids } \\
\text { discharge } \\
\text { (tons) }\end{array}$ \\
\hline
\end{tabular}

\section{Historical conditions}

Duchesne River near Randlett, Utah---- 4,247 $\quad 135,700 \quad 555,700 \quad 460,200$

Adjustments for development

Irrigation:

Duchesne River basin upstream from

Duchesne, Utah--

Remaining drainage area-n 4,088

$159 \quad 6,500 \quad(+) 12,000$

$(-) 22,700$

129,200

$(+) 222,000$

$(-) 302,800$

Transbasin diversions:

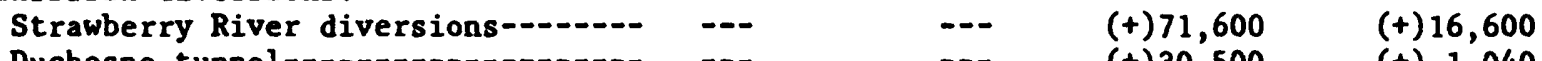

Duchesne tunnel-

$\cdots$

$\underline{(+) 30,500}$

(t) 1,040

Natural conditions

Duchesne River near Randlett, Utah--- $\quad--\quad \quad---\quad 891,800 \quad 152,340$

Estimated mean annual natural dissolved-solids concentration for water years 1914-57: 125 milligrams per liter

\footnotetext{
${ }^{1}$ Based on Iorns and others (1965).
} 
Table 21.--Mass balance for site 11, streamflow-gaging station 09306500 white River near Watson, Utah, for water years 1914-571

$$
[--, \text { no data] }
$$

\begin{tabular}{|c|c|c|c|c|}
\hline Mass-balance component & $\begin{array}{l}\text { Drainage } \\
\text { area } \\
\text { (square } \\
\text { miles) }\end{array}$ & $\begin{array}{l}\text { Irrigated } \\
\text { area } \\
\text { (acres) }\end{array}$ & $\begin{array}{l}\text { Mean annual } \\
\text { streamflow } \\
\text { (acre-feet) }\end{array}$ & $\begin{array}{l}\text { Mean annual } \\
\text { dissolved- } \\
\text { solids } \\
\text { discharge } \\
\text { (tons) }\end{array}$ \\
\hline
\end{tabular}

\section{Historical conditions}

White River near Watson, Utah-....- 4,020

$29,900 \quad 553,500$

330,600

Adjustments for development

Irrigation:

White River basin between Buford and Meeker, Colo...........

Meeker, Colo.

352
3,668

11,000

18,900

(+) 11,000

$2(-) 53,150$

a rea- $-0 .--$

\section{Natural conditions}

White River near Watson, Utah-

Estimated mean annual natural dissolved-solids concentration for water years 1914-57:

210 milligrams per liter

${ }^{1}$ Based on Iorns and others (1965).

2Includes an estimate of 100 tons per year per 1,000 people in the basin.

${ }^{3}$ Includes 4,000 tons per year from oil wells. 
Table 22.--Mass balance for site 12, streamflow-gaging station 09315000 Green River at Green River, Utah, for water years $1914-57^{1}$

$$
[--, \text { no data }]
$$

\begin{tabular}{lcccc}
\hline Mass-balance component & $\begin{array}{c}\text { Drainage } \\
\text { area } \\
\text { (square } \\
\text { miles) }\end{array}$ & $\begin{array}{c}\text { Irrigated } \\
\text { area } \\
\text { (acres) }\end{array}$ & $\begin{array}{c}\text { Mean annual } \\
\text { streamflow } \\
\text { (acre-feet) }\end{array}$ & $\begin{array}{c}\text { ansissolved- } \\
\text { solids } \\
\text { (tons) }\end{array}$ \\
\hline
\end{tabular}

Historical conditions

Green River at Green River, Utah------ $40,590 \quad 550,600 \quad 4,558,000 \quad 2,652,000$

\section{Adjustments for development}

Irrigation:

Little Snake River basin above Dixon,

Wyo. - -

Ashley Creek basin--.--

Remaining drainage area--...-..-

$\begin{array}{rr}340 & 4,000 \\ 167 & 23,800 \\ 13,316 & 54,900\end{array}$

$(+) 5,000$

$(+) 42,500$

$(-) 5,100$

$2(+) 68,625$

$(-) 49,400$

$(-) 188,870$

Transbasin diversions:

Fairview ditch ${ }^{3}-\ldots$

$+-\quad(+) 830$

${ }^{4}(+) 140$

Effects in upstream areas:

Green River near Greendale, Utah---- 15,090

Yampa River near Maybell, Colo....- $\quad 3,410$

Duchesne River near Randlett, Utah-- 4,247

251,000

(t) 220,270

51,300

(t) 40,960

$(-) 317,100$

$4,247 \quad 135,700$

(t) 336,100

$(-) 29,860$

White River near Watson, Utah-.--.--

29,900

(t) 33,600

$(-) 307,860$

$(-) 164,750$

\section{Natural conditions}

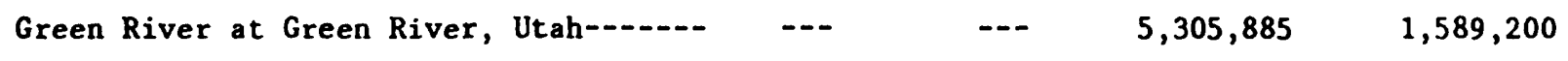

Estimated mean annual natural dissolved-solids concentration for water years 1914-57: 220 milligrams per liter

\footnotetext{
${ }^{1}$ Based on Iorns and others (1965).

${ }^{2}$ Based on consumptive rate of 1.25 acre-feet per acre of irrigated land.

${ }^{3}$ One-half of streamflow and dissolved-solids discharge for ditch assumed to come from
} the San Rafael River basin.

${ }^{4}$ Based on a weighted mean concentration of 125 milligrams per liter. 
Table 23.--Mass balance for site 13, streamflow-gaging station 09328500 San Rafael River near Green River, Utah, for water years 1914-571

$$
[\cdots, \text { no data }]
$$

\begin{tabular}{|c|c|c|c|c|}
\hline Mass-balance component & $\begin{array}{l}\text { Drainage } \\
\text { area } \\
\text { (square } \\
\text { miles) }\end{array}$ & $\begin{array}{c}\text { Irrigated } \\
\text { area } \\
\text { (acres) }\end{array}$ & $\begin{array}{l}\text { Mean annual } \\
\text { streamflow } \\
\text { (acre-feet) }\end{array}$ & $\begin{array}{c}\text { Mean annual } \\
\text { dissolved- } \\
\text { solids } \\
\text { discharge } \\
\text { (tons) }\end{array}$ \\
\hline
\end{tabular}

\section{Historical conditions}

San Rafael River near Green River, Utah-

Adjustments for development

Irrigation:

San Rafael River upstream from

Castle Dale, Utah- 377

Remaining drainage area-_._... 1,251

$$
\begin{array}{r}
36,000 \\
0
\end{array}
$$

(+) 91,800

$(-) 115,400$

Transbasin diversions:

Fairview ditch ${ }^{2}$, Candland ditch, Ephraim tunnel, Larsen tunnel, Horseshoe tunnel, Coal Fork ditch, Twin Creek tunnel, Cedar Creek tunnel, Black Canyon ditch, Spring City tunnel, Reeder ditch, Madsen

ditch, John August ditch-n w $\quad$ (t)9,250 $\quad 3(+) 1,570$

\section{Natural conditions}

San Rafael River near Green River, Utah-co-cor near Green River,

$203,150 \quad 76,470$

Estimated mean annual natural dissolved-solids concentration for water years 1914-57: 275 milligrams per liter

${ }^{1}$ Based on Iorns and others (1965).

${ }^{2}$ One-half of streamflow and dissolved-solids load for ditch assumed to come from the Price River basin.

${ }^{3}$ Based on a weighted mean concentration of 125 milligrams per liter. 
Table 24.--Mass balance for site 14, streamflow-gaging station 09355500 San Juan River near Archuleta, N. Mex., for water years 1914-571

$$
[\cdots, \text { no data] }
$$

\begin{tabular}{|c|c|c|c|c|}
\hline Mass-balance component & $\begin{array}{l}\text { Drainage } \\
\text { area } \\
\text { (square } \\
\text { miles) }\end{array}$ & $\begin{array}{c}\text { Irrigated } \\
\text { area } \\
\text { (acres) }\end{array}$ & $\begin{array}{l}\text { Mean annual } \\
\text { streamflow } \\
\text { (acre-feet) }\end{array}$ & $\begin{array}{c}\text { Mean annual } \\
\text { dissolved- } \\
\text { solids } \\
\text { discharge } \\
\text { (tons) }\end{array}$ \\
\hline
\end{tabular}

Historical conditions

San Juan River near Archuleta,

N. Mex. ${ }^{2}-1,046,520 \quad 31,000 \quad 1,260 \quad 172,370$

Adjustments for development

Irrigation:

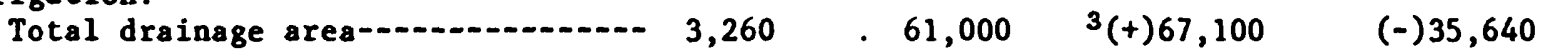

Transbasin diversions:

Treasure Pass ditch, Fuchs ditch, Raber-Lohr ditch, Squaw Pass

ditch, Piedra Pass ditch-....... -.. $\quad$ (t)2,750

$(+) 260$

Natural conditions

San Juan River near Archuleta,

N. Mex.

Estimated mean annual natural dissolved-solids concentration for water years 1914-57:

90 milligrams per liter

\section{${ }^{1}$ Based on Iorns and others (1965).}

'Streamflow, dissolved-solids discharge and irrigated-area data were estimated based on data for the San Juan River at Arboles, Colo.; and the San Juan River near Blanco, N. Mex.

${ }^{3}$ Based on a consumptive rate of 1.1 acre-feet per acre of irrigated 1 and. 
Table 25.--Mass balance for site 15, streamflow-gaging station 09379500 San Juan River near Bluff, Utah, for water years 1914-571

$$
\text { [-.., no data] }
$$

\begin{tabular}{|c|c|c|c|c|}
\hline Mass-balance component & $\begin{array}{l}\text { Drainage } \\
\text { area } \\
\text { (square } \\
\text { miles) }\end{array}$ & $\begin{array}{l}\text { Irrigated } \\
\text { area } \\
\text { (acres) }\end{array}$ & $\begin{array}{l}\text { Mean annual } \\
\text { streamflow } \\
\text { (acre-feet) }\end{array}$ & $\begin{array}{c}\text { Mean annual } \\
\text { dissolved- } \\
\text { solids } \\
\text { discharge } \\
\text { (tons) }\end{array}$ \\
\hline
\end{tabular}

Historical conditions

San Juan River near Bluff, Utah----- 23,000 206,400 2,028,000 $\quad 997,000$

Adjustments for development

Irrigation:

La Plata River basin in Colo., downstream from Hesperus, Colo..- $294 \quad 16,500 \quad(+) 18,200 \quad(-) 6,500$

La Plata River basin in N. Mex.-.- $252 \quad 9,500 \quad(+) 10,500 \quad(-) 13,100$

Remaining drainage area-.......- 19,194 $119,400 \quad(+) 164,750 \quad(-) 233,120$

Transbasin diversions:

Import from the Dolores River

basin-..

Effects in upstream areas:

San Juan River near Archuleta,

N. Mex.-

\section{Natural conditions}

San Juan River near Bluff, Utah- -.-- $\quad--\quad \quad \cdots \quad 2,191,300 \quad 691,900$

Estimated mean annual natural dissolved-solids concentration for water years 1914-57:

230 milligrams per liter

${ }^{1}$ Based on Iorns and others (1965): 
Table 26.--Mass balance for site 16, streamflow-gaging station 09380000 Colorado River at Lees Ferry, Ariz., for water years 1914-57 ${ }^{1}$

$$
\text { [--., no data] }
$$

\begin{tabular}{lcccc}
\hline Mass-balance component & $\begin{array}{c}\text { Drainage } \\
\text { area } \\
\text { (square } \\
\text { miles) }\end{array}$ & $\begin{array}{c}\text { Irrigated } \\
\text { area }\end{array}$ & $\begin{array}{c}\text { Mean annual } \\
\text { dissolved- } \\
\text { solids } \\
\text { streamflow } \\
\text { (acre-feet) }\end{array}$ & $\begin{array}{c}\text { discharge } \\
\text { (tons) }\end{array}$ \\
\hline
\end{tabular}

Historical conditions

Colorado River at Lees Ferry, Ariz.-- $107,540 \quad 1,413,000 \quad 12,733,110 \quad 8,676,330$

Adjustments for development

Irrigation:

Intervening drainage area-....... 18,222

Municipal and industrial:

Crystal Geyser well near Green

River, Utah-

Effects in upstream areas:

Colorado River near Cisco, Utah---- $24,100 \quad 577,700 \quad(+) 1,189,100 \quad(-) 1,990,385$

$\begin{array}{llllll}\text { Green River at Green River Utah---- } 40,590 & 550,600 & (+) 747,885 & (-) 1,062,800\end{array}$

San Rafael River near Green River,

Utah--

San Juan River near Bluff, Utah- - $23,000 \quad 206,400 \quad \underline{(+) 163,300 \quad(-) 305,100}$

Natural conditions

Colorado River at Lees Ferry, Ariz.-- $\quad \ldots \quad$ 14,991,243 $\quad 5,117,185$

Estimated mean annual natural dissolved-solids concentration for water years 1914-57: 250 milligrams per liter

${ }^{1}$ Based on Iorns and others (1965).

${ }^{2}$ Based on a consumptive rate of 1.35 acre-feet per acre of irrigated 1 and.

${ }^{3}$ Streamflow would not accrue to channel during natural conditions. 